medRxiv preprint doi: https://doi.org/10.1101/2021.01.18.21250031; this version posted January 20, 2021. The copyright holder for this preprint (which was not certified by peer review) is the author/funder, who has granted medRxiv a license to display the preprint in perpetuity.

All rights reserved. No reuse allowed without permission.

\title{
Cumulative effects of particulate matter pollution and meteorological variables on the risk of influenza-like illness in Bialystok, Poland
}

Kacper Toczylowski ${ }^{{ }^{*}}$, Magdalena Wietlicka-Piszcz ${ }^{2}$, Magdalena Grabowska ${ }^{3}$, and Artur Sulik $^{1}$

${ }^{1}$ Department of Pediatric Infectious Diseases, Medical University of Bialystok, Waszyngtona 17, 15-

274 Bialystok, Poland; kacper.toczylowski@umb.edu.pl (K.T.); artur.sulik@umb.edu.pl (A.S.)

${ }^{2}$ Department of Theoretical Foundations of Biomedical Sciences and Medical Computer Science, Nicolaus Copernicus University in Torun, L. Rydygier Collegium Medicum in Bydgoszcz, 9 M.

Sklodowska-Curie St., 85-094 Bydgoszcz, Poland, mpiszcz@cm.umk.pl

${ }^{3}$ Department of Hydrobiology, University of Bialystok, Ciolkowskiego 1J, 15-245 Bialystok, Poland,

*Correspondence: kacper.toczylowski@umb.edu.pl; Tel.: +48-857-450-680; Department of Pediatric Infectious Diseases, Medical University of Bialystok, Waszyngtona 17, 15-274 Bialystok, Poland

\section{Abstract}

The cold season is usually accompanied by an increased incidence of respiratory infections and increased air pollution from combustion sources. As we are facing the growing numbers of COVID-19 cases caused by the novel SARS-CoV-2 coronavirus, an understanding of the impact of air pollutants and meteorological variables on the incidence of respiratory infections is crucial. The influenza-like illness (ILI) incidence might be used as a close proxy for the circulation of influenza viruses. Recently, SARS-CoV-2 has also been detected in patients with ILI. Using distributed lag nonlinear models, we analyzed the association between ILI, meteorological variables and particulate matter concentration in Bialystok, Poland, from 2013-2019. We found an exponential relation between cumulative $\mathrm{PM}_{2.5}$ pollution and the incidence of ILI that remained significant after adjusting for air temperatures and a long-term trend. Pollution had the greatest effect during the same week, but the risk of ILI was increased for the four following weeks. The risk of ILI was also increased by low air temperatures, low absolute humidity, and high wind speed. Altogether, our results show that all measures implemented to decrease $\mathrm{PM}_{2.5}$ concentrations would be beneficial to reduce the transmission of SARS-CoV-2 and other respiratory infections.

\section{Capsule summary}

Low/medium high concentrations of particulate matter pollution increase the risk of influenza-like illness. The effect is independent from air temperatures and lasts for the four following weeks.

\section{Keywords}

Particulate matter, air pollution, influenza-like illness, influenza, COVID-19

\section{Background}

Particulate matter (PM) is an important air pollutant. It comprises multiple components and size fractions. The sizes of the inhalable particles are limited to those with aerodynamic diameters of $10 \mu \mathrm{m}$ or less $\left(\mathrm{PM}_{10}\right) . \mathrm{PM}_{10}$ is the sum of fine particles with aerodynamic diameters of $2.5 \mu \mathrm{m}$ or less $\left(\mathrm{PM}_{2.5}\right)$ and coarse particles with aerodynamic diameters between $2.5 \mu \mathrm{m}$ and $10 \mu \mathrm{m}\left(\mathrm{PM}_{10-2.5}\right) . \mathrm{PM}_{2.5}$ originates primarily from combustion sources, while $\mathrm{PM}_{10-2.5}$ is produced by agriculture, mining, construction activities and road dust resuspension (WHO, 2006). The health effects of particulate matter may differ because of differences in chemical composition and penetration into the respiratory tract (Kim et al., 2015). Smaller particles have been shown to be more harmful to human 
health than larger particles because of the potential to be deposited in the alveoli and the ability to cross the lung-blood barrier (Sun et al., 2010). The evidence for airborne particulate matter (PM) and its public health impact consistently shows adverse health effects at exposure levels that are currently experienced by urban populations in both developed and developing countries (WHO, 2006). The range of health effects is broad. Exposure to air pollutants has been shown to be the cause of increased emergency room visits, exacerbation of chronic respiratory and cardiovascular diseases, decreased lung function, and premature mortality (Kim et al., 2015). In response to the accumulating evidence on the adverse effects of air pollution, the WHO published air quality guidelines with daily and annual thresholds for mean concentrations of $\mathrm{PM}_{2.5}$ and $\mathrm{PM}_{10}$. The guidelines stipulate that $\mathrm{PM}_{2.5}$ concentrations should not exceed the $25 \mu \mathrm{g} / \mathrm{m}^{3}$ daily mean or 10 $\mu \mathrm{g} / \mathrm{m}^{3}$ annual mean. For $\mathrm{PM}_{10}$, concentration thresholds are $50 \mu \mathrm{g} / \mathrm{m}^{3}$ and $20 \mu \mathrm{g} / \mathrm{m}^{3}$ for daily and annual means, respectively (WHO, 2006).

Based on accumulating evidence, PM increases the incidence of influenza and influenza-like illness (Huang et al., 2016; Silva et al., 2014; Su et al., 2019). Influenza-like illness (ILI) is a common acute respiratory syndrome defined by the WHO as fever $\left(>38^{\circ} \mathrm{C}\right)$ with cough or sore throat, which began in the last 10 days (Fukuda and WHO, 2009). Each year, ILI imposes a significant burden to public health and leads to substantial morbidity and economic costs (Feng et al., 2020; Tsai et al., 2014).

According to the latest WHO database of observed annual mean $\mathrm{PM}_{2.5}$ concentrations, air quality in Poland is considered unsafe, with many of Europe's 50 most polluted cities located in Poland ("Air quality statistics - European Environment Agency," 2020). High pollution levels in Polish cities are caused mainly by coal power plants and residential heating with wood and coal (JudaRezler et al., 2020). Following the recognition that Poland is facing high air pollution levels, researchers have focused on the associated health effects. However, little is known about the influence of air pollution on the respiratory infection incidence in Poland. In a recent study, Slama et al. reported a positive association between air pollutants and hospitalizations for respiratory disease in Polish cities (Slama et al., 2019). This and other studies have shown that people exposed to air pollutants may be at high risk for infection within a lag period from zero to ten days, which represents the usual incubation periods of respiratory infections (Huang et al., 2016; Liu et al., 2019; $\mathrm{Xu}$ et al., 2013). Little is known about the effect of air pollution on respiratory infections beyond a lag of two weeks.

The current COVID-19 outbreak has been caused by the emergence of a new coronavirus, SARS-CoV-2, that very quickly spread in the human population. A similarity between COVID-19 and ILI symptoms has been observed. The presence of SARS-CoV-2-positive swabs in patients with ILI has been reported in several studies (Boëlle et al., 2020; Kong et al., 2020; Yu et al., 2020, p. 2). Moreover, air pollution was suggested to be a major factor contributing to the aggressive spread of this virus (Conticini et al., 2020). Cases of COVID-19 in Poland have been increasing since September 2020, and with the beginning of the cold season, an increase in air pollution is expected.

Meteorological variables play an important role in the physical and chemical transformation of PM and its horizontal and vertical transport (Degórska et al., 2016). Therefore, we aimed to assess the association between the risk of ILI and air pollution over longer time lags, considering the potential influences of meteorological variables and long-term trends.

\section{Patients and methods}



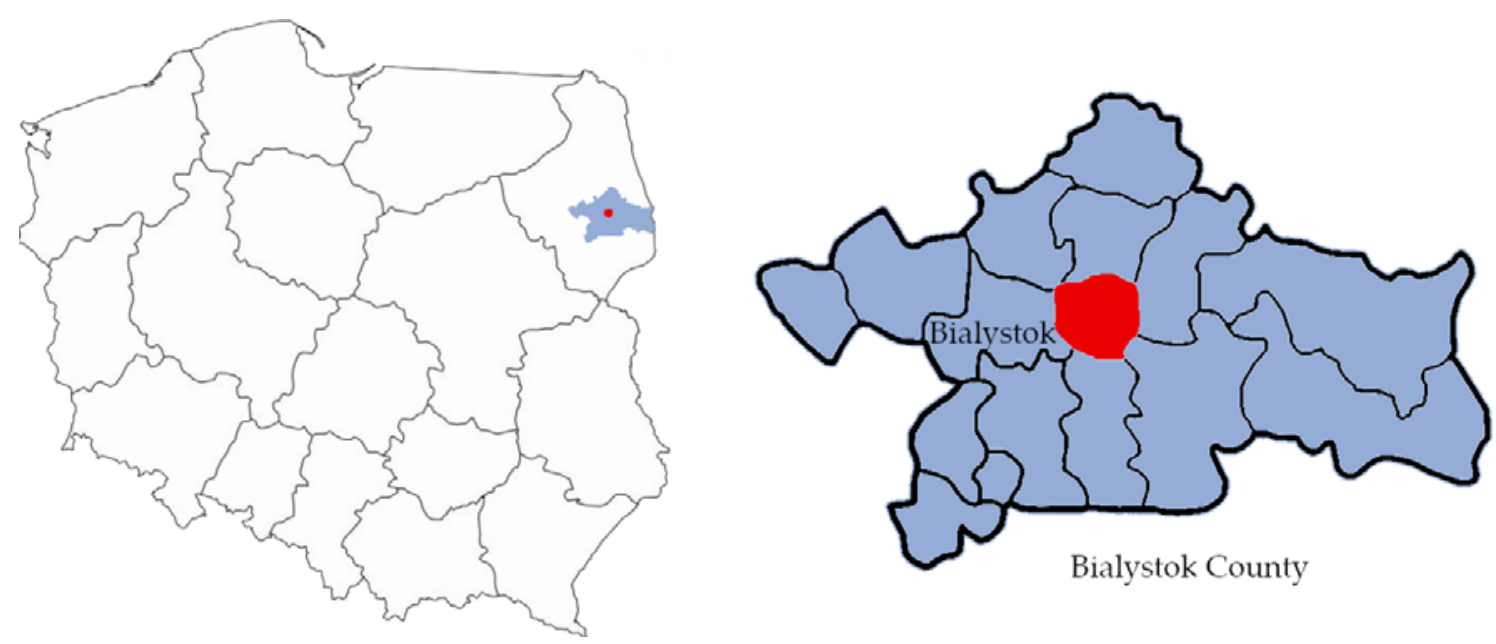

Figure 1. The geographical location of Bialystok and Bialystok County in northeastern Poland.

\section{Influenza-like illness data}

Bialystok is the largest city in northeastern Poland and one of the largest cities in Poland in terms of population density (2913.8 people per sq. km). Bialystok City and Bialystok County cover an area of 3086.76 square kilometers and are inhabited by approximately 435,000 people, 297,000 (68\%) of whom live in Bialystok City ("Statistics Poland - Local Data Bank," 2020). The city has a warm humid continental climate (Merkel, 2020).

The data on the number of suspected influenza and influenza cases in Bialystok city and Bialystok County (Figure 1) were obtained from the Department of Epidemiology of the Municipal Sanitary and Epidemiological Station. Influenza is a notifiable disease in Poland. The Department collects all reports of confirmed and suspected influenza cases that come from all hospitals and all outpatient clinics located in the city and county. Reports of confirmed and suspected influenza cases (ICD-10 codes: $\mathrm{J} 10.0, \mathrm{~J} 10.1, \mathrm{~J} 10.8, \mathrm{~J} 11.0, \mathrm{~J} 11.1$, and $\mathrm{J} 11.8$ ) are submitted manually by hospitals and clinics with no automated reporting system integrated with medical document management software. The data are then reported weekly by the Municipal Sanitary and Epidemiological Station. No data on the percentage of confirmed cases in the total reported number are available. Therefore, throughout the manuscript, both confirmed and suspected influenza cases are analyzed jointly as ILIs.

\section{Meteorological and air pollution data}

The data on the concentrations of air pollutants were obtained from two fixed stations, Waszyngtona Street and Warszawska Street, which are located in the city center 2 kilometers apart and have a maximum distance to the city borders of 6 kilometers. The concentrations of $\mathrm{PM}_{2.5}$ were measured with BAM 1020 (Met One Instruments Inc., OR, USA) (Waszyngtona Street), and the concentration of $\mathrm{PM}_{10}$ was measured with TEOM 1405F (Thermo Fisher Scientific, MA, USA) (Warszawska Street). Daily meteorological data (air temperature, relative humidity, wind speed, precipitation, precipitation and sunshine duration) for the analyzed period were obtained from the Institute of Meteorology and Water Management. Absolute humidity was calculated from temperature and relative humidity. For statistical analyses, we used mean weekly values. We found that $6 \%$ of the mean daily concentrations of $\mathrm{PM}_{2.5}$ were missing. Weeks with missing data for more than five days were excluded from the analysis. 
medRxiv preprint doi: https://doi.org/10.1101/2021.01.18.21250031; this version posted January 20, 2021. The copyright holder for this preprint (which was not certified by peer review) is the author/funder, who has granted medRxiv a license to display the preprint in perpetuity. All rights reserved. No reuse allowed without permission.

\section{Statistical analysis}

The patient and meteorological data collected from January 2013 to December 2019 were sorted, categorized according to weeks, and preliminarily analyzed with a simple correlation analysis (Spearman's r). Then, the association between meteorological factors, air pollution and the incidence of ILI was further studied with distributed lag nonlinear models (DLNMs) developed by Gasparrini (Gasparrini et al., 2010). The DLNM framework enables the modeling of the exposure-response relationship together with the lag-response relationship; thus, it enables the modeling of delayed effects after a specific exposure. In this paper, we used the DLNM to investigate the relationship between the incidence of ILI, meteorological factors and air pollution expressed as the levels of $\mathrm{PM}_{2.5}$ and $\mathrm{PM}_{10}$. The delayed effects of the abovementioned environmental factors have also been studied.

The modeling of the relationship between the incidence of ILI and the environmental factors was performed for the following meteorological factors: air temperature, relative humidity, absolute humidity, sunshine duration, precipitation, precipitation duration, and wind speed and for air pollution expressed as the levels of $\mathrm{PM}_{2.5}$ and $\mathrm{PM}_{10}$. Poisson regression models with a quasi-Poisson function were used for the analysis to address the issue of the overdispersion of the response data (counts of ILI cases). The number of ILI cases was included in the model as the dependent variable, while the considered environmental factors were included as independent variables. The following formula represents the model structure:

$$
\log \left[E\left(Y_{t}\right)\right]=\alpha+n s\left(X_{i}, d f\right)+n s(P M, d f, \operatorname{lag}, d f)+n s(\text { Time }, d f)
$$

where $E\left(Y_{t}\right)$ represents the weekly number of ILI cases in week t, $\alpha$ is the intercept, $X_{i}$ represents the environmental factors (temperature, etc.), $n s$ is the natural cubic spline, $P M$ is the concentration of particulate matter, $d f$ represents the degree of freedom, and Time represents the long-term trend.

Initially, the analysis was performed for each environmental factor separately, and then the models adjusted for air pollutant levels were fitted to the data. Because of the relatively strong correlations between the meteorological factors, one meteorological factor, one air pollutant and the long-term trend were included in each model. The Akaike Information Criterion for quasi-Poisson function (qAIC) was used to select the degrees of freedom for environmental factors (1-10 df) and for the maximum number of lag weeks included in the model (Burnham and Anderson, 1998). According to the results of the performed analysis (lowest value of qAIC) and previous studies (Feng et al., 2016, p. 5; Liang et al., 2014; Vandini et al., 2013), we decided to include the delayed effects for $\mathrm{PM}_{2.5}$ and for wind speed. The effects of the meteorological factors temperature, wind speed and precipitation were modeled using $1 d f$, sunshine duration $4 d f$, humidity $3 d f$ and precipitation duration $2 d f$. For wind speed, the maximum lag of 2 weeks was included (a range of 1-8 maximum weeks of lag). The effects of air pollution caused by $\mathrm{PM}_{2.5}$ and $\mathrm{PM}_{10}$ were modeled by $n s$ of $1 d f$, and for $\mathrm{PM}_{2.5}$, the maximum lag of 5 weeks was also included. The maximum lag was chosen based on the qAIC and the stability of the shape of the risk of the ILI-PM 2.5 relationship. The long-term trend was modeled using ns with $1 \mathrm{df} /$ year.

The reference levels were defined as the median values of each of the analyzed variables to calculate relative risks (RRs). The sensitivity analysis was performed by calculating the qAIC and changing $d f$ for environmental variables.

The statistical analysis was performed using R software, version 3.6.2, with the packages dlnm, mgcv and bbmle.

\section{Results}


medRxiv preprint doi: https://doi.org/10.1101/2021.01.18.21250031; this version posted January 20, 2021. The copyright holder for this preprint (which was not certified by peer review) is the author/funder, who has granted medRxiv a license to display the preprint in perpetuity.

All rights reserved. No reuse allowed without permission.

During the analyzed period, 345,987 cases were reported, of which 155,249 (45\%) were children under the age of 15, and 31,179 (9\%) were individuals over 65 years of age (Table S1 in the Supplementary materials). The incidence rate based on the number of reported cases was 11.4 (95\% $\mathrm{Cl}, 11.3-11.5)$ episodes per 100 person-years. Data on the sex of the patients were unavailable. The median number of cases in a week was 700 (range from 0 cases to 6,309 cases). The number of ILI cases peaked once in each season, in January and February, when the mean temperatures approached $0^{\circ} \mathrm{C}$ (Figure $\mathrm{S} 1$ in the Supplementary materials).

Table S1. Reported influenza-like illness cases in Bialystok and Bialystok County divided by year and by age group.

\begin{tabular}{|c|c|c|c|c|c|c|c|c|}
\hline & 2013 & 2014 & 2015 & 2016 & 2017 & 2018 & 2019 & 2013-2019 \\
\hline $0-4$ & 11,092 & 8,982 & 10,041 & 14,794 & 16,092 & 10,606 & 10,396 & 82,003 \\
\hline $5-14$ & 10,574 & 7,869 & 9,084 & 14,064 & 14,350 & 10,038 & 7,267 & 73,246 \\
\hline $15-64$ & 25,332 & 16,376 & 18,966 & 27,674 & 31,900 & 22,752 & 16,559 & 159,559 \\
\hline $65+$ & 4,716 & 2,563 & 3,224 & 4,975 & 6,226 & 5,711 & 3,764 & 31,179 \\
\hline Total & 51,714 & 35,790 & 41,315 & 61,507 & 68,568 & 49,107 & 37,986 & 345,987 \\
\hline
\end{tabular}

Concentrations of $\mathrm{PM}_{2.5}$ and $\mathrm{PM}_{10}$ increased in the fall and in the winter (Figure S1 in the Supplementary materials). The daily mean concentrations of $\mathrm{PM}_{2.5}$ exceeded WHO standards on 767 (30\%) days and that of $\mathrm{PM}_{10}$ exceeded the standards on 129 (5\%) days. The annual mean concentrations of $\mathrm{PM}_{2.5}$ exceeded the standards every year, and those of $\mathrm{PM}_{10}$ were within the recommended levels in 2019 only (Table S2 in the Supplementary materials).

Table S2. Annual and 24-hour mean concentrations of particulate matter $\left(\mu \mathrm{g} / \mathrm{m}^{3}\right)$ in Bialystok.

\begin{tabular}{|c|c|c|c|c|c|c|c|c|c|c|}
\hline Year & & Annual mean & SD & Min & P25 & Median & P75 & Max & $\begin{array}{c}\text { n (\%) }>\text { WHO daily } \\
\text { guidelines }\end{array}$ & n (\%) missing \\
\hline \multirow[t]{2}{*}{2013} & $\mathrm{PM}_{2.5}$ & 22.9 & 11.1 & 3.8 & 15.2 & 20.3 & 28.1 & 75.2 & $122(35 \%)$ & $21(6 \%)$ \\
\hline & $\mathrm{PM}_{10}$ & 23.2 & 13.7 & 3.9 & 13.9 & 20.3 & 28.8 & 96.5 & $13(4 \%)$ & 0 \\
\hline \multirow[t]{2}{*}{2014} & $\mathrm{PM}_{2.5}$ & 24.9 & 11.7 & 5.9 & 16.0 & 22.9 & 32.8 & 69.7 & $151(42 \%)$ & $4(1 \%)$ \\
\hline & $\mathrm{PM}_{10}$ & 26.5 & 15.8 & 5.8 & 15.2 & 22.1 & 33.3 & 97.1 & $30(8 \%)$ & 0 \\
\hline \multirow[t]{2}{*}{2015} & $\mathrm{PM}_{2.5}$ & 24.9 & 14.7 & 6.1 & 15.0 & 19.9 & 31.6 & 91.0 & $125(36 \%)$ & $16(5 \%)$ \\
\hline & $\mathrm{PM}_{10}$ & 25.3 & 18.1 & 4.7 & 13.1 & 19.6 & 30.4 & 115.4 & $40(11 \%)$ & 0 \\
\hline \multirow[t]{2}{*}{2016} & $\mathrm{PM}_{2.5}$ & 19.8 & 9.1 & 3.3 & 12.9 & 18.1 & 25.2 & 65.2 & 77 (26\%) & $65(22 \%)$ \\
\hline & $\mathrm{PM}_{10}$ & 20.2 & 12.5 & 1.7 & 11.8 & 16.7 & 24.7 & 86.9 & $12(3 \%)$ & 0 \\
\hline \multirow[t]{2}{*}{2017} & $\mathrm{PM}_{2.5}$ & 21.0 & 12.9 & 2.7 & 12.9 & 17.9 & 25.8 & 129.7 & $92(27 \%)$ & $23(7 \%)$ \\
\hline & $\mathrm{PM}_{10}$ & 20.2 & 14.4 & 2.7 & 11.5 & 17.0 & 24.2 & 139.1 & $12(3 \%)$ & 0 \\
\hline \multirow[t]{2}{*}{2018} & $\mathrm{PM}_{2.5}$ & 24.0 & 13.3 & 2.4 & 14.2 & 21.4 & 29.9 & 88.4 & $132(37 \%)$ & $9(3 \%)$ \\
\hline & $\mathrm{PM}_{10}$ & 22.1 & 14.6 & 2.8 & 11.9 & 18.2 & 27.9 & 97.4 & $19(5 \%)$ & $1(<1 \%)$ \\
\hline \multirow[t]{2}{*}{2019} & $\mathrm{PM}_{2.5}$ & 19.0 & 9.3 & 2.9 & 12.8 & 17.6 & 22.3 & 64.4 & $68(19 \%)$ & $3(1 \%)$ \\
\hline & $\mathrm{PM}_{10}$ & 18.6 & 10.1 & 2.7 & 11.8 & 16.8 & 22.5 & 91.2 & $3(1 \%)$ & 0 \\
\hline
\end{tabular}



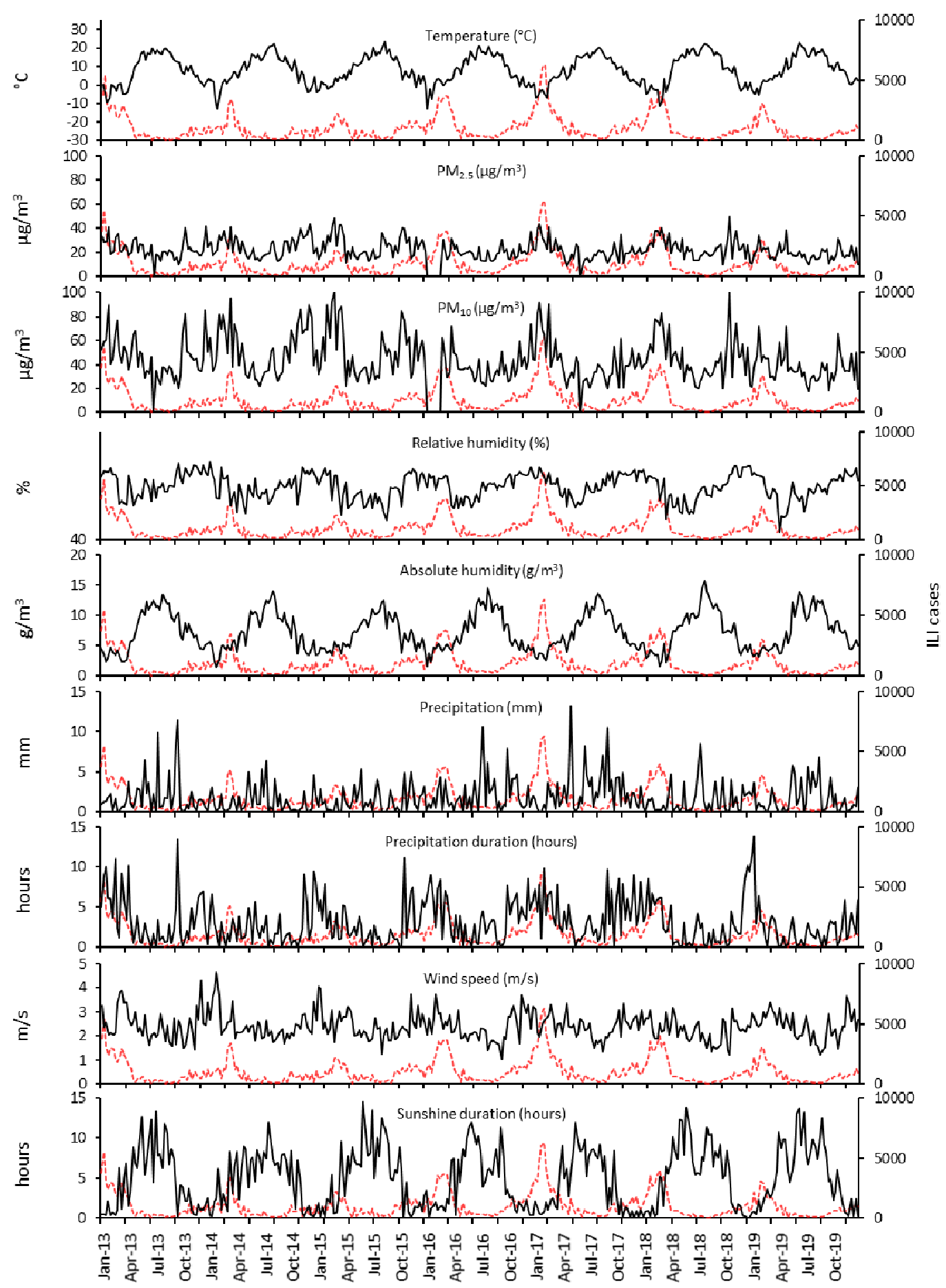

Figure S1. The number of weekly influenza-like cases (red dotted lines) plotted against meteorological and air pollution data (black lines) from Bialystok, Poland, from January 2013 December 2019.

From 2013 to 2019, the weekly mean concentration of $\mathrm{PM}_{2.5}$ was $22.41 \mu \mathrm{g} / \mathrm{m}^{3}$, ranging from $9.04 \mu \mathrm{g} / \mathrm{m}^{3}$ to $49.77 \mu \mathrm{g} / \mathrm{m}^{3}$, and that of $\mathrm{PM}_{10}$ was $22.34 \mu \mathrm{g} / \mathrm{m}^{3}$, ranging from $6.56 \mu \mathrm{g} / \mathrm{m}^{3}$ to 55.99 $\mu \mathrm{g} / \mathrm{m}^{3}$ (Table 1 ). The weekly mean temperature was $8.28{ }^{\circ} \mathrm{C}$, ranging from $-12.90^{\circ} \mathrm{C}$ to $23.11{ }^{\circ} \mathrm{C}$. The average weekly relative humidity (RH) was $79.3 \%$ (ranging from $45.46 \%$ to $97.30 \%$ ), absolute 
medRxiv preprint doi: https://doi.org/10.1101/2021.01.18.21250031; this version posted January 20, 2021. The copyright holder for this preprint (which was not certified by peer review) is the author/funder, who has granted medRxiv a license to display the preprint in perpetuity.

All rights reserved. No reuse allowed without permission.

humidity (AH) was $7.3 \mathrm{~g} / \mathrm{m}^{3}$ (ranging from 1.34 to $15.91 \mathrm{~g} / \mathrm{m}^{3}$ ), wind speed was $2.40 \mathrm{~m} / \mathrm{s}$ (ranging from $1.05 \mathrm{~m} / \mathrm{s}$ to $4.66 \mathrm{~m} / \mathrm{s}$ ), precipitation was $1.79 \mathrm{~mm}$ (ranging from $0.0 \mathrm{~mm}$ to $13.29 \mathrm{~mm}$ ), precipitation duration was 3.09 hours (ranging from 0.0 hours to 13.85 hours), and sunshine duration was 4.99 hours (ranging from 0.0 hours to 14.59 hours).

Table 1. Weekly meteorological variables, air pollutants and the incidence of influenza-like illness in Bialystok, January 2013 - December 2019

\begin{tabular}{|c|c|c|c|c|c|c|c|c|c|}
\hline & Mean & SD & Min & P5 & P25 & Median & P75 & P95 & Max \\
\hline Number of cases of ILI & $1,029.72$ & $1,034.50$ & 0.00 & 108.0 & 313.75 & 700.00 & $1,280.50$ & $3,227.0$ & $6,309.00$ \\
\hline Temperature $\left({ }^{\circ} \mathrm{C}\right)$ & 8.28 & 8.03 & -12.90 & -5.51 & 2.02 & 7.99 & 15.83 & 21.00 & 23.11 \\
\hline Relative humidity (\%) & 79.30 & 9.81 & 45.46 & 57.50 & 72.28 & 80.51 & 87.52 & 96.40 & 97.30 \\
\hline Absolute humidity $\left(\mathrm{g} / \mathrm{m}^{3}\right)$ & 7.30 & 3.18 & 1.34 & 2.97 & 4.65 & 6.92 & 10.00 & 12.79 & 15.91 \\
\hline Wind speed $(\mathrm{m} / \mathrm{s})$ & 2.40 & 0.57 & 1.05 & 1.00 & 2.01 & 2.33 & 2.71 & 4.10 & 4.66 \\
\hline Precipitation (mm) & 1.79 & 2.09 & 0.00 & 0.00 & 0.29 & 1.06 & 2.46 & 9.82 & 13.29 \\
\hline Precipitation duration (hours) & 3.09 & 2.75 & 0.00 & 0.00 & 1.00 & 2.35 & 4.46 & 13.40 & 13.85 \\
\hline Sunshine duration (hours) & 4.99 & 3.75 & 0.00 & 0.20 & 1.42 & 4.88 & 7.93 & 13.16 & 14.59 \\
\hline $\mathrm{PM}_{2.5}(\mu \mathrm{g} / \mathrm{m} 3)$ & 22.34 & 7.96 & 6.56 & 7.50 & 15.26 & 19.60 & 26.86 & 44.70 & 49.77 \\
\hline $\mathrm{PM}_{10}(\mu \mathrm{g} / \mathrm{m} 3)$ & 22.41 & 9.93 & 9.04 & 8.60 & 16.83 & 20.39 & 26.90 & 50.42 & 55.99 \\
\hline
\end{tabular}

The analysis of Spearman correlations showed that the incidence of ILI was positively correlated with weekly mean values of relative humidity, wind speed, precipitation duration, concentration of $\mathrm{PM}_{2.5}$ and concentration of $\mathrm{PM}_{10}$. In contrast, weekly mean values for temperature, precipitation, and sunshine durations were negatively correlated with the incidence of ILI (Table S3 in in the Supplementary materials). When correlations were analyzed in the peak of the flu season only (December - February), ILI cases correlated with $\mathrm{PM}_{2.5}(\mathrm{R}=0.31, \mathrm{p}=0.007), \mathrm{PM}_{10}(\mathrm{R}=0.27 ; \mathrm{p}=0.02)$, mean temperature $(R=-0.25 ; p=0.02)$, and absolute humidity $(R=-0.30 ; p=0.005)$. No correlation with relative humidity, wind speed, sunshine duration or precipitation was observed in that time frame. 
medRxiv preprint doi: https://doi.org/10.1101/2021.01.18.21250031; this version posted January 20, 2021. The copyright holder for this preprint (which was not certified by peer review) is the author/funder, who has granted medRxiv a license to display the preprint in perpetuity. All rights reserved. No reuse allowed without permission.

Table S3. Spearman's correlation coefficients between the environmental factors and the incidence of influenza-like illness.

\begin{tabular}{|c|c|c|c|c|c|c|c|c|c|c|}
\hline & $\begin{array}{c}\text { Number of } \\
\text { cases }\end{array}$ & $\begin{array}{l}\text { Temperatu } \\
\text { re }\left({ }^{\circ} \mathrm{C}\right)\end{array}$ & $\begin{array}{c}\text { Relative } \\
\text { humidity } \\
\text { (\%) }\end{array}$ & $\begin{array}{c}\text { Absolute } \\
\text { humidity } \\
\left(\mathrm{g} / \mathrm{m}^{3}\right)\end{array}$ & $\begin{array}{l}\text { Wind } \\
\text { speed } \\
(\mathrm{m} / \mathrm{s})\end{array}$ & $\begin{array}{l}\text { Precipitati } \\
\text { on }(\mathrm{mm})\end{array}$ & $\begin{array}{c}\text { Precipitati } \\
\text { on } \\
\text { duration } \\
\text { (hours) }\end{array}$ & $\begin{array}{c}\text { Sunshine } \\
\text { duration } \\
\text { (hours) }\end{array}$ & $\begin{array}{c}\mathrm{PM}_{2.5} \\
\left(\mu \mathrm{g} / \mathrm{m}^{3}\right)\end{array}$ & $\begin{array}{c}\mathrm{PM}_{10} \\
\left(\mathrm{\mu g} / \mathrm{m}^{3}\right)\end{array}$ \\
\hline Number of cases & - & 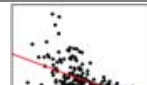 & $\because$ & 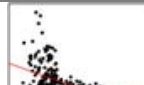 & & $\ddot{\because}$ & $\because$ & & & \\
\hline Temperature $\left({ }^{\circ} \mathrm{C}\right)$ & $-0.78 * * *$ & - & 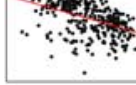 & & & & & & & \\
\hline Relative humidity (\%) & $0.33 * * *$ & $-0.5 * * *$ & - & 的得: & : & & & & & \\
\hline Absolute humidity $\left(\mathrm{g} / \mathrm{m}^{3}\right)$ & $-0,77$ & 0,97 & $-0,29$ & - & & & & & & 5 \\
\hline Wind speed $(\mathrm{m} / \mathrm{s})$ & $0.43 * * *$ & $-0.52 * * *$ & $0.13 *$ & $-0,54 * * *$ & - & $\because$ & & & & \\
\hline Precipitation (mm) & $-0.15 * *$ & $0.15^{* *}$ & $0.23 * * *$ & $0,25 * * *$ & NS & - & & & & \\
\hline $\begin{array}{l}\text { Precipitation duration } \\
\text { (hours) }\end{array}$ & $0.42 * * *$ & $-0.55 * * *$ & $0.61 * * *$ & $-0,43 * * *$ & $0.39 * * *$ & $0.58 * * *$ & - & 4 & & is \\
\hline $\begin{array}{l}\text { Sunshine duration } \\
\text { (hours) }\end{array}$ & $-0.57 * * *$ & $0.75 * * *$ & $-0.82 * * *$ & $0,62 * * *$ & $-0.43 * * *$ & $-0.17 * *$ & $-0.73 * * *$ & - & 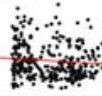 & (4) \\
\hline $\mathrm{PM}_{2.5}\left(\mu \mathrm{g} / \mathrm{m}^{3}\right)$ & $0.4^{* * *}$ & $-0.34 * * *$ & NS & $-0,37 * * *$ & NS & $-0.51 * * *$ & $-0.2 * * *$ & NS & & \\
\hline
\end{tabular}

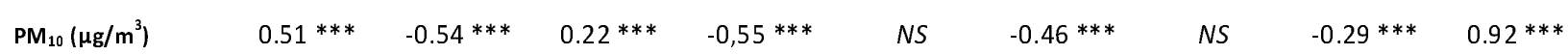

* indicates $\mathrm{p}<0.05 ; * *$ indicates $\mathrm{p}<0.01 ; * * *$ indicates $\mathrm{p}<0.001$; 

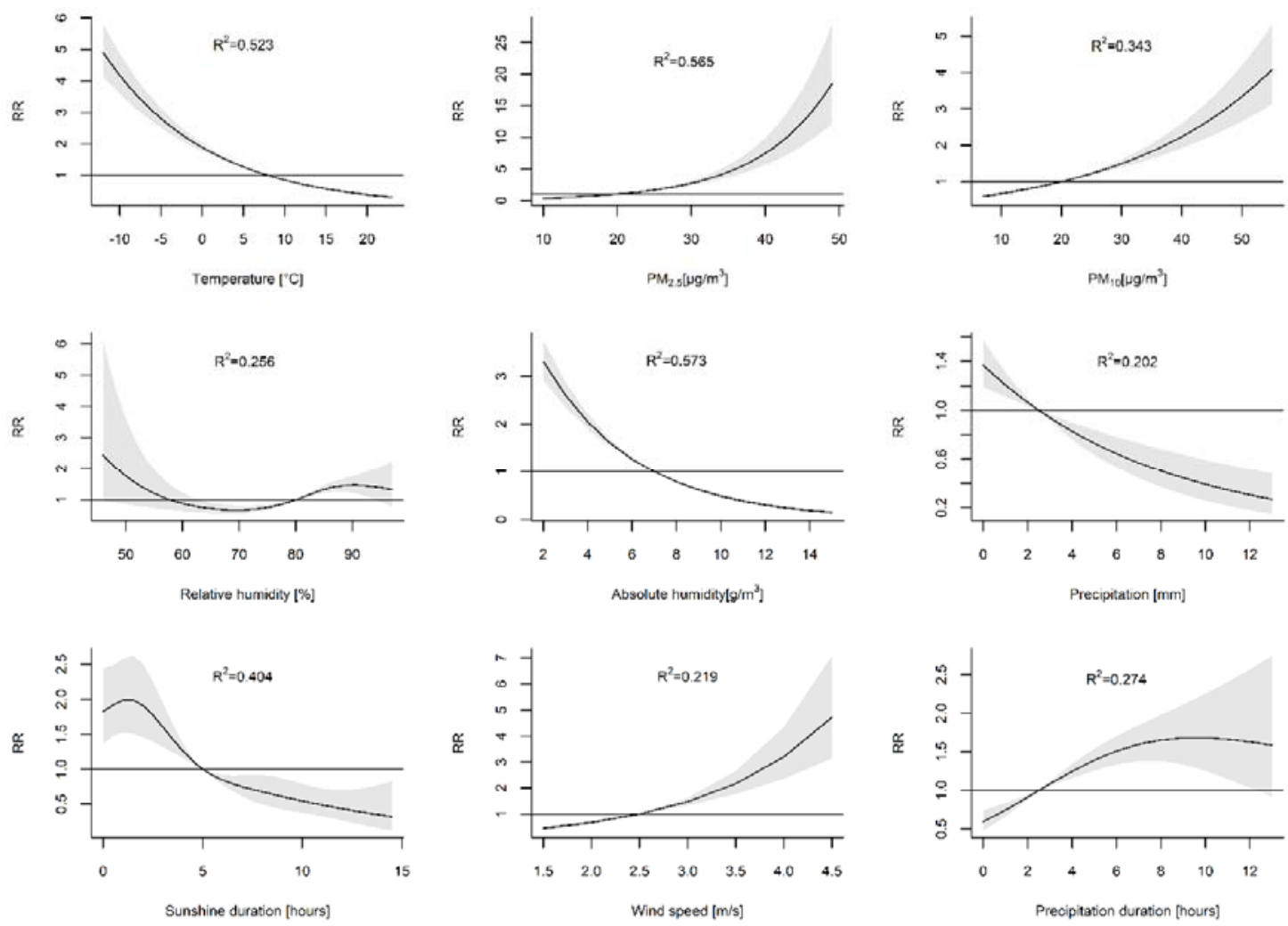

Figure 2. The association between environmental factors and the relative risk (RR) with $95 \%$ confidence interval $(\mathrm{Cl})$ of influenza-like illness. The analysis was performed for each environmental factor separately. The reference levels were defined as the median values of each of the analyzed variables to calculate RRs.

For each of the variables described above, a DLNM model illustrating the relationship between the number of ILI cases and the values of the considered variable was fitted. The delayed effect was included for $\mathrm{PM}_{2.5}$. The results of the model estimation are presented as relative risks (RRs) and are shown in Figure 2. For each considered environmental variable, the association between the RR of ILI and the values of weekly means of the covariate are shown. As shown in Figure 2 , the weekly mean temperature and weekly mean concentrations of $\mathrm{PM}_{2.5}$ were the most significant risk factors exponentially associated with the incidence of ILI, as evidenced by the highest relative risks (RRs). The values of the coefficient of determination $\left(R^{2}\right)$ were 0.523 and 0.563 , respectively, which indicates that over $50 \%$ of variability in the dependent variable is explained by the models. The RR of the cold effect at the $5^{\text {th }}$ percentile $\left(-5.51^{\circ} \mathrm{C}\right)$ was $2.81(95 \% \mathrm{Cl}, 2.51-3.13)$ and increased to $4.89(95 \% \mathrm{Cl}, 4.13-5.80)$ at the minimum value $\left(-12.9^{\circ} \mathrm{C}\right)$ compared to the median $\left(7.99^{\circ} \mathrm{C}\right)$. Compared to the median, the RR of the high air pollution effect at the $95^{\text {th }}$ percentile of the $\mathrm{PM}_{2.5}$ concentration was 13.18 (95\% Cl, 9.02-19.28), increasing to 19.92 (95\% Cl, 12.82-30.95) at the maximum value. The RRs of concentrations of $\mathrm{PM}_{10}$ were $3.34(95 \% \mathrm{Cl}, 2.66-4.19)$ at the $95^{\text {th }}$ percentile and $4.08(95 \% \mathrm{Cl}, 3.13-5.32)$ at the maximum value compared to the median $\left(\mathrm{R}^{2}=0.343\right)$. The relative humidity displayed a weak U-shaped relation with the number of cases. The RRs of the dry and moist effects at the $5^{\text {th }}$ and 95th percentiles, respectively, were insignificant because $95 \% \mathrm{Cls}$ included a null risk of one. The RR of the relative humidity effect peaked at $90 \%$ and reached 1.47 $\left(95 \% \mathrm{Cl}, 1.23-1.75 ; \mathrm{R}^{2}, 0.256\right)$. The dry and moist effects were analyzed again using the absolute humidity calculated from relative humidity and temperature. The $R R$ at the $5^{\text {th }}$ percentile of absolute humidity $\left(3 \mathrm{~g} / \mathrm{m}^{3}\right)$ was $2.61(95 \% \mathrm{Cl}, 2.36-2.88)$, whereas at the $95^{\text {th }}$ percentile $\left(13 \mathrm{~g} / \mathrm{m}^{3}\right)$, the RR was 
0.24 (95\% Cl, 0.20-0.28; $\mathrm{R}^{2}, 0.573$ ). The RR of the high wind speed effect was 3.20 ( $95 \% \mathrm{Cl}, 2.36-4.34$; $R^{2}, 0.219$ ) at the $95^{\text {th }}$ percentile $(4 \mathrm{~m} / \mathrm{s}$ ). The RR of the effect of low sunshine hours (0 hours) was 1.83 $(95 \% \mathrm{Cl}, 1.36-2.44)$ and that of the low precipitation $(0 \mathrm{~mm})$ effect was 1.37 (95\% $\mathrm{Cl}, 1.19-1.57)$. In contrast, the effect of the precipitation duration was positive and peaked at 9 hours (RR, 1.68; $95 \%$ $\mathrm{Cl}, 1.34-2.11 ; \mathrm{R}^{2}, 0.274$ ); however, that effect was insignificant at the $95^{\text {th }}$ percentile (12 hours).

Subsequently, these models were adjusted for $\mathrm{PM}_{2.5}$. The adjusted RRs of the cold effect were $2.29(95 \% \mathrm{Cl}, 2.03-2.58)$ at the $5^{\text {th }}$ percentile and $3.57(95 \% \mathrm{Cl}, 2.97-4.3)$ at the minimum value $\left(R^{2}=0.703\right)$. The effect of adjusted $\mathrm{PM}_{10}$ was $1.67(95 \% \mathrm{Cl}, 1.19-2.34)$ at the $95^{\text {th }}$ percentile and 1.82 $(95 \% \mathrm{Cl}, 1.22-2.69)$ at the maximum value $\left(\mathrm{R}^{2}=0.548\right)$. The highest $\mathrm{RR}$ values of relative humidity effects after including $\mathrm{PM}_{2.5}$ concentrations decreased to $1.15(95 \% \mathrm{Cl}, 1.05-1.25)$ at a relative humidity of $86 \%$. When absolute humidity was analyzed, the adjusted RR of the dry effect at the $5^{\text {th }}$ percentile was $2.14(95 \% \mathrm{Cl}, 1.93-2.38)$. The adjusted RR of the moisture effect at the $95^{\text {th }}$ percentile of absolute humidity was $0.32\left(95 \% \mathrm{Cl}, 0.27-0.37 ; R^{2}, 0.723\right)$. The adjusted $R R$ of the high wind speed effect was $2.82\left(95 \% \mathrm{Cl}, 2.20-3.63 ; R^{2}, 0.603\right)$. The adjusted $R R$ of the effect of low sunshine hours $(0$ hours) was $1.35\left(95 \% \mathrm{Cl}, 1.07-1.71 ; \mathrm{R}^{2}, 0.616\right)$ and that of low precipitation $(0 \mathrm{~mm})$ was $1.15(95 \% \mathrm{Cl}$, $\left.1.02-1.29 ; R^{2}, 0.576\right)$. The adjusted effect of the precipitation duration peaked at 11 hours (RR, 1.48; $95 \% \mathrm{Cl}, 1.09-2.01 ; \mathrm{R}^{2}, 0.585$ ) but was insignificant at the $95^{\text {th }}$ percentile ( 12 hours).
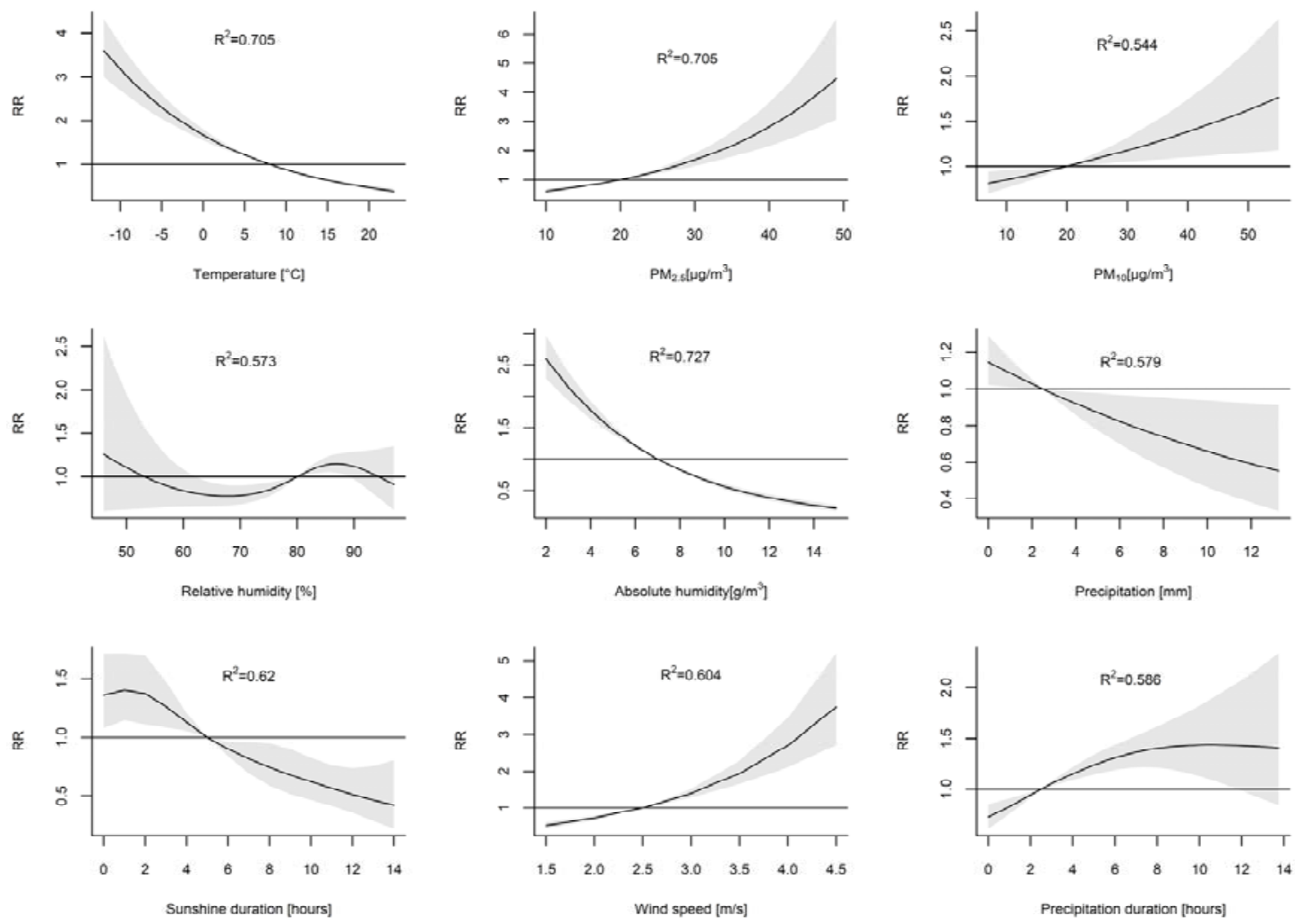

Figure 3. The association between environmental factors and the relative risk (RR) with $95 \%$ confidence interval $(\mathrm{Cl})$ of influenza-like illness. The models for climatic variables were adjusted for mean concentrations of $\mathrm{PM}_{2.5}$ and the long-term trend. The models for $\mathrm{PM}_{2.5}$ and for $\mathrm{PM}_{10}$ were adjusted for the mean temperature and the long-term trend. The reference levels were defined as the median values of each of the analyzed variables to calculate RRs. 
Considering that temperature is the main driver of ILI of all meteorological factors, the air pollution effect was adjusted for mean temperatures (Figure 3). The adjusted RRs of the PM 2.5 concentrations were $3.85(95 \% \mathrm{Cl}, 2.72-5.45)$ at the 95 th percentile and $4.77(95 \% \mathrm{Cl}, 3.19-7.15)$ at the maximum value. The adjusted RRs of the $\mathrm{PM}_{10}$ concentrations were 1.42 (1.15-1.75) and 1.50 $(1.17-1.92)$ at the $95^{\text {th }}$ percentile and the maximum value, respectively $\left(R^{2}=0.534\right)$. Based on the considered DLNM models, the model including $\mathrm{PM}_{2.5}$, temperature and long-term data shows the most significant association with the dynamics of ILI prevalence $\left(R^{2}=0.703\right)$. Figure 4 shows the observed and predicted numbers of ILI cases in the considered time period.

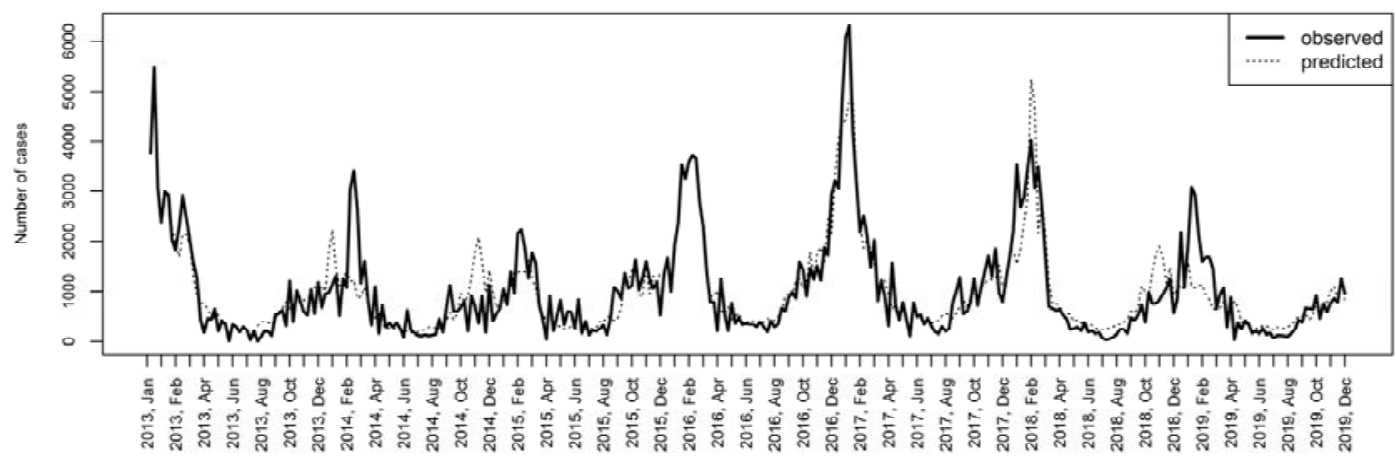

Figure 4. The observed and predicted (according to the model including temperature, $\mathrm{PM}_{2.5}$ and the long-term trend as covariates) number of influenza-like illness cases. $R^{2}=0.703$

Additionally, we considered that $\mathrm{PM}_{10}$ reflects the concentrations of both fine $\left(\mathrm{PM}_{2.5}\right)$ and coarse particles $\left(\mathrm{PM}_{10-2.5}\right)$, and therefore the RRs of the $\mathrm{PM}_{10}$ pollution effect were analyzed in a model including the concentration of $\mathrm{PM}_{2.5}$ as a covariate (data not shown). After including $\mathrm{PM}_{2.5}$ in the model, the RRs of the $\mathrm{PM}_{10}$ effect were $1.67(95 \% \mathrm{Cl}, 1.19-2.34)$ at the $95^{\text {th }}$ percentile and 1.82 $(95 \% \mathrm{Cl}, 1.22-2.69)$ at the maximum value. Furthermore, we assessed the RRs of the cold effect adjusted for the concentrations of both $\mathrm{PM}_{2.5}$ and $\mathrm{PM}_{10}$. The adjusted RRs of the cold effect were $2.42(95 \% \mathrm{Cl}, 2.01-2.57)$ at the $5^{\text {th }}$ percentile and $3.54(95 \% \mathrm{Cl}, 2.92-4.28)$ at the minimum value.

The estimated effects of the $\mathrm{PM}_{2.5}$ concentrations were plotted against lag weeks in a model including weekly mean temperatures and a long-term trend as covariates to identify the cumulative effects of $\mathrm{PM}_{2.5}$ on ILI cases (Figure $5 \mathrm{~A}$ and $\mathrm{B}$ ). The effect of $\mathrm{PM}_{2.5}$ decreased over time but remained significant for lag weeks 0 through 4 . The RRs $(95 \% \mathrm{Cls})$ at the $95^{\text {th }}$ percentile were $1.45(1.31-1.61)$, 1.37 (1.26-1.48), 1.29 (1.21-1.36), 1.21 (1.15-1.27), 1.14 (1.08-1.21), and 1.08 (0.99-1.16) at lag weeks 0 through 5 , respectively. We estimated that a $10 \mu \mathrm{g} / \mathrm{m}^{3}$ increase in the mean weekly $\mathrm{PM}_{2.5}$ concentration (an increase from 20 to $30 \mu \mathrm{g} / \mathrm{m}^{3}$ ) caused a $16 \%$ increase in the risk of ILI (RR, 1.16; $95 \% \mathrm{Cl} ; 1.11-1.21$ ) in the same week (lag 0). That risk decreased over time (Figure $5 \mathrm{C}$ ). The estimates for the five following weeks (lag 1-5) were as follows: 1.13 (95\% Cl, 1.10-1.17), 1.11 (95\% Cl, 1.081.13), 1.08 (95\% Cl, 1.06-1.10), 1.05 (95\% Cl, 1.03-1.08), and 1.03 (95\% Cl, 1.00-1.06). 
Lag $=0$

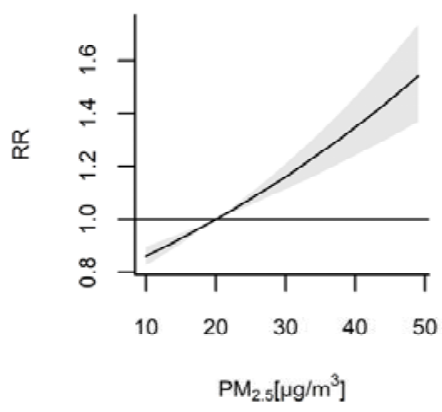

Lag= 3

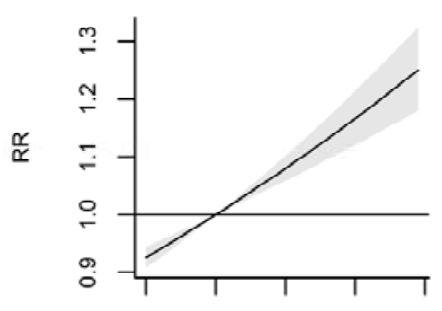

A

B

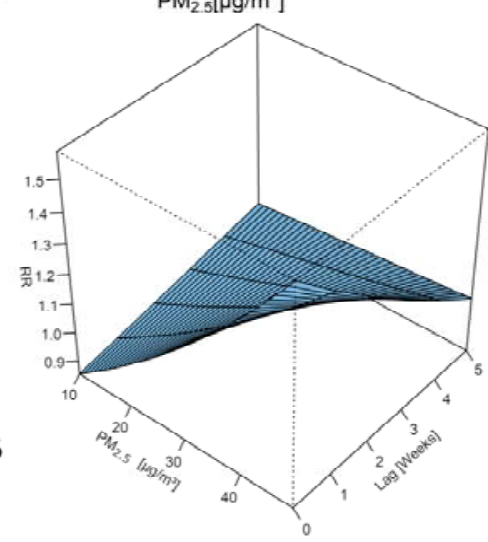

Lag= 1

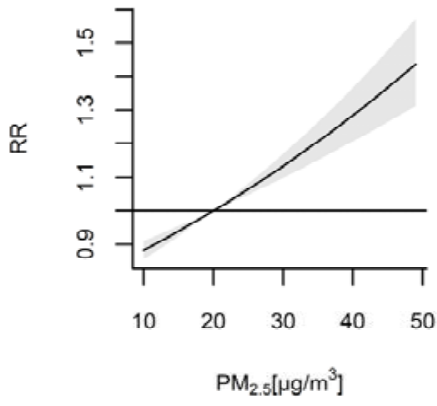

Lag= 4

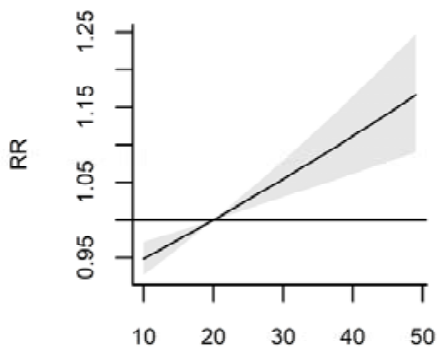

$\mathrm{PM}_{2.5}\left[\mathrm{\mu g} / \mathrm{m}^{3}\right]$
Lag= 2

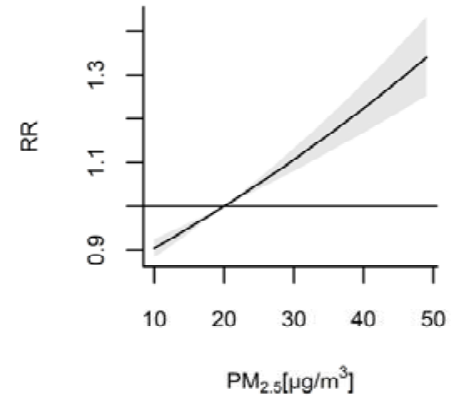

Lag= 5

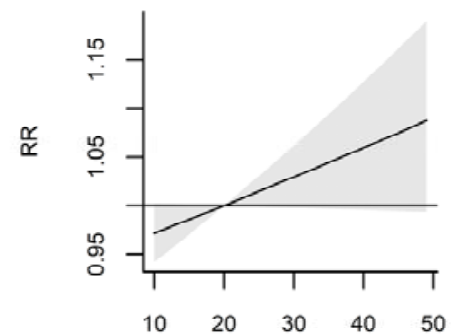

$\mathrm{PM}_{2.5}\left[\mu \mathrm{g} / \mathrm{m}^{3}\right]$

Figure 5. (A) The association between the concentration of $\mathrm{PM}_{2.5}$ and the relative risk (RR) of the incidence of influenza-like illness (ILI) is depicted as the estimated exposure-response curves for lags of 0 to 5 weeks with $95 \%$ confidence intervals (Cls). (B) The association between the concentration of $\mathrm{PM}_{2.5}$ and the RR of the incidence of ILI is depicted as the estimated exposure-lag-response surface. The model was adjusted for the mean air temperature and a long-term trend. (C) The estimated lagresponse curves for $\mathrm{PM}_{2.5}=30 \mu \mathrm{g} / \mathrm{m}^{3}$ with $95 \% \mathrm{Cl}$.

As indicated by the qAIC, we also assessed the effect of wind speed over lag weeks in a model including $\mathrm{PM}_{2.5}$ and a long-term trend as covariates (Figure S2 in the Supplementary materials). The effect of a high wind speed decreased over time but was significant for lag weeks 0 through 2 . The RRs $(95 \% \mathrm{Cls})$ at the $95^{\text {th }}$ percentile were $1.56(1.32-1.85), 1.41(1.3-1.54)$, and 1.28 (1.09-1.5) for lag weeks 0 through 2, respectively. 

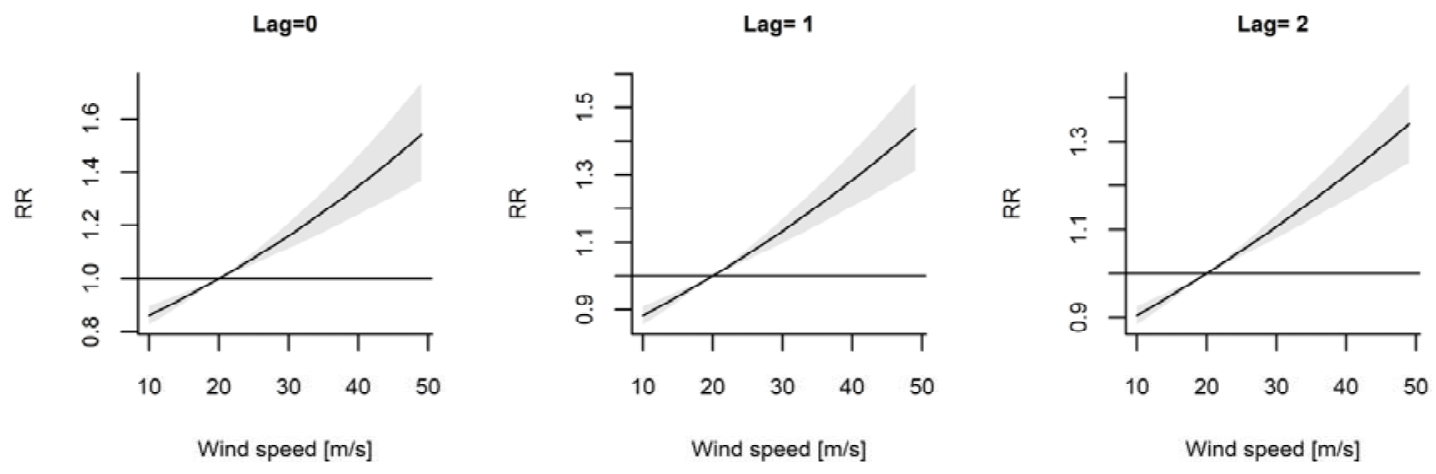

Figure S2. The association between wind speed and the relative risk of the incidence of influenza-like illness is shown as the estimated exposure-lag-response surface. The model was adjusted for the $\mathrm{PM}_{2.5}$ concentration and a long-term trend.

\section{Discussion}

Air pollution may increase the incidence of a wide range of diseases, including heart disease, stroke, and lung cancer (Brunekreef and Holgate, 2002; Laden et al., 2000; Polichetti et al., 2009; Raaschou-Nielsen et al., 2013). Numerous studies have confirmed that exposure to ambient air pollutants is strongly associated with the local transmission of respiratory infections (Chen et al., 2010; Domingo and Rovira, 2020; Feng et al., 2016; Huang et al., 2016; Silva et al., 2014; Su et al., 2019). This study provides additional evidence for the association between air pollution and ILI. We have shown that the cumulative effect of an increase in the $\mathrm{PM}_{2.5}$ concentration is exponentially associated with the increase in ILI risk in Bialystok, Poland, after adjusting for air temperature and a long-term trend. The distributed lag nonlinear analysis including $\mathrm{PM}_{2.5}$, temperature and a long-term trend as covariates showed that the model was able to explain as much as $70 \%$ of the variability in the number of observed ILI cases in Bialystok, Poland in 2013-2019. The concentration of $\mathrm{PM}_{2.5}$ in Bialystok throughout the study frequently exceeded the levels recommended by the WHO. However, in our study, the mean $\mathrm{PM}_{2.5}$ concentrations were several times lower than those reported in previous studies linking air pollution to ILI (Feng et al., 2016; Huang et al., 2016). Nevertheless, the effect of ambient air pollution on the ILI incidence was evident, indicating that the relationship is not limited to highly polluted regions. Moreover, the high pollution effect extended beyond the incubation periods of influenza and other respiratory tract infections, which are usually shorter than two weeks (Stellrecht, 2017). Our results show that high concentrations of $\mathrm{PM}_{2.5}$ increase the risk of ILI during the same week (lag 0 ) and for up to 4 subsequent weeks (lag weeks 1-4). Therefore, the underlying mechanisms linking air pollution and the incidence of respiratory infections are not limited to acute effects only.

The leading epidemiological concept of respiratory infections is that infections are spread by direct transmission from person to person, such as touching an infected person or touching the fomites that the infected person has contaminated. Respiratory droplets can also be deposited directly on a person in close proximity to the infected person. However, after droplets are expired, the liquid content starts to evaporate. Some droplets become so small that they are free to travel in the air and carry pathogens contained inside over tens of meters from where they originated. Previous studies have suggested that airborne transmission should be considered possible in infections caused by influenza viruses (Cowling et al., 2013; Hammond et al., 1989; Tellier, 2009; Tellier et al., 2019). The same might be hypothesized for ILI, even though pathogens other than influenza virus are frequently detected in ILI patients [38]. In multiple studies airborne transmission 
medRxiv preprint doi: https://doi.org/10.1101/2021.01.18.21250031; this version posted January 20, 2021. The copyright holder for this preprint (which was not certified by peer review) is the author/funder, who has granted medRxiv a license to display the preprint in perpetuity.

All rights reserved. No reuse allowed without permission.

was suggested to participate in the spread of different respiratory pathogens responsible for ILI like, parainfluenza viruses (Burke et al., 2013), RSV (Aintablian et al., 1998; Kulkarni et al., 2011), rhinoviruses (Dick et al., 1987; Myatt et al., 2004), adenoviruses (Couch et al., 1966; Echavarria et al., 2000), human coronaviruses, including SARS-CoV-2 (da Silva et al., 2020, p. 2; Morawska and Cao, 2020, p. 2; Yu et al., 2004), and other pathogens (Tang et al., 2006).

Particulate matter was suggested to serve as a vector for the transport of pathogenic microorganisms (Chen et al., 2010; Griffin et al., 2001). The airborne transmission of pathogens further depends on their survival in aerosolized droplets, which in turn is subject to variations in temperature, humidity, and solar radiation (Sooryanarain and Elankumaran, 2015). For example, influenza virus transmission is most efficient under cold, dry conditions (Lowen and Steel, 2014). Both correlation and DLNM analyses revealed that temperature, absolute humidity, and wind speed were the meteorological factors that best predicted ILI activity in Bialystok, Poland. Other factors, including precipitation, sunshine duration and relative humidity, showed lower correlations with the incidence of ILI. Similar observations were reported in an analysis conducted in other Northern European countries (lanevski et al., 2019). Relative humidity was not predictive of ILI cases in our study. In the nonlinear analysis, an increasing trend towards low and high RH values with a decreased risk was observed at intermediate $\mathrm{RH}$. Thus, both high and low values of RH facilitate the spread of ILI. The results of experimental studies are consistent with these observations. In laboratory settings, influenza virus was maximally stable at low $\mathrm{RH}$, minimally stable at mid-range $\mathrm{RH}$, and moderately stable at high RH (Lowen et al., 2007; Schaffer et al., 1976). However, humidity is also reported as absolute humidity defined as the absolute amount of water in the air. We found that absolute humidity was a better predictor of ILI seasonality than relative humidity. Decreasing AH exponentially increased the risk of ILI, even if particulate matter was included in the model. Similar observations were documented in previous studies (Shoji et al., 2011; Tamerius et al., 2013). A positive association between ILI cases and wind speed was also noted. The effect remained significant for up to three weeks after exposure (lag weeks 0-2). Wind was shown to promote the spread of various viruses over short and large distances (Sundell et al., 2016; Ypma et al., 2013). We hypothesize that wind facilitates the spread of ILI by transporting aerosolized pathogens in the area. The calculated lag effect of two weeks possibly reflects the maxiumum incubation period of respiratory pathogens causing ILI. Although the wind-borne route alone is insufficient to explain the seasonality of ILI, we show that it contributes substantially to the increase in the risk of infection.

Meteorological variables affect the concentration of particulate matter in the air; however, the interplay between these two factors is complicated. We found negative correlations between PM temperature, absolute humidity, and precipitation. The negative correlation between PM and temperature might be explained by emissions due to residential heating in the cold season (Degórska et al., 2016). Studies linking humidity and PM have shown conflicting results. In the analysis from the state environmental monitoring program in Poland (Degórska et al., 2016), the authors described significant negative correlations between $\mathrm{PM}_{10}$ and $\mathrm{RH}$ observed in the warm season from April to September. However, a study from the USA reported a positive correlation between $\mathrm{RH}$ and $\mathrm{PM}_{2.5}$ concentrations in several regions (Tai et al., 2010). These contradictory results may be explained by the relative abundance of each component of the PM. Sulfates and nitrates were shown to be positively related to $\mathrm{RH}$, reflecting in-cloud sulfate formation and the $\mathrm{RH}$-dependent ammonium nitrate formation. The correlation between $\mathrm{RH}$ and carbons is negative, which possibly reflects sources from fires and combustion (Tai et al., 2010). Moreover, increased RH may be accompanied by precipitation. Rainfall has a washing effect on the levels of $\mathrm{PM}_{2.5}$ in the air (Ouyang et al., 2015). In the absence of precipitation, PM was suggested to act as condensation nucleus for water and virus particles (Chen et al., 2010; Griffin et al., 2001; Liu et al., 2018). 
medRxiv preprint doi: https://doi.org/10.1101/2021.01.18.21250031; this version posted January 20, 2021. The copyright holder for this preprint (which was not certified by peer review) is the author/funder, who has granted medRxiv a license to display the preprint in perpetuity. All rights reserved. No reuse allowed without permission.

Notably, pathogens causing ILI differ in structure; thus, meteorological factors probably exert distinct effects on their transmission, making the data difficult to interpret. However, fluctuations in ILI activity in the community are affected not only by the transmission and survival of pathogens in the environment but also by host susceptibility. Exposure to air pollutants impacts the host response to infections. The underlying possible mechanisms related to this process are complex (Ciencewicki and Jaspers, 2007). Ambient air pollution likely disrupts host defenses, including both innate and cellmediated immune responses against infections. Exposure to PM containing environmentally persistent free radicals (EPFRs), which are found in most combustion-derived PM, was shown to cause pulmonary oxidative stress, which leads to local immunosuppression and the exacerbation of influenza in mice (Lee et al., 2014; Saravia et al., 2014). Another study reported enhanced viral attachment and entry due to exposure to diesel exhaust (Jaspers et al., 2005). Particulate matter can also activate inflammatory signaling cascades, change macrophage morphology (Li et al., 2010; Yang et al., 2019) and precipitate tissue remodeling in the lung (Pinkerton et al., 2000). Exposure to $\mathrm{PM}_{2.5}$ alters the expression of multiple genes in lung tissue (Sancini et al., 2014). Importantly, the angiotensin-converting enzyme 2 (ACE2) receptor present on the cells was overexpressed following exposure to $\mathrm{PM}_{2.5}$. Thus, $\mathrm{PM}$ might plausibly increase the probability of SARS-CoV-2 infection, as ACE2 is the key receptor mediating virus entry (Comunian et al., 2020, p. 19).

The study is subject to some limitations. First, we only used two air pollution measurement sources from Bialystok City, limiting the spatial representativeness of the present analysis. People living outside Bialystok City might have been exposed to slightly different air pollution levels. A vast majority of residents of this area live in towns with similar levels of urban development; therefore, we believe that pollution levels in Bialystok city can serve as a close proxy for the county. Second, our data might potentially suffer from underreporting of influenza cases. In our opinion, underreporting tends to occur in consistent patterns throughout the years; hence, the seasonal variation in ILI cases still reflects the true burden of ILI in the region. Third, we did not stratify the relative risks by age group. As previously shown, the effects of air pollution depend on age (Feng et al., 2016). Our results cannot be generalized to the entire population, and the calculated relative risks should be interpreted with caution.

In conclusion, our study describes a clear association between $\mathrm{PM}_{2.5}$ pollution and the incidence of ILI in northeastern Poland, despite the relatively low concentrations of particulate matter recorded in the study period. Pollution exerted the greatest effect during the same week, but the risk of ILI was increased in the four subsequent weeks. Because SARS-CoV-2 cases are still increasing, further studies elucidating the mechanisms linking air pollution and susceptibility to acute respiratory infections are urgently needed. Altogether, our study indicates that all measures implemented to decrease $\mathrm{PM}_{2.5}$ concentrations would be beneficial to reduce the transmission of COVID-19 and other respiratory infections.

\section{Author Contributions}

Conceptualization, K.T.; methodology, K.T. and M.W.-P.; data curation, K.T.; writing-original draft preparation, K.T. and M.W.-P.; writing-review and editing, K.T., M.W.-P., M.G and A.S.; supervision, M.G and A.S.; funding acquisition, K.T. All authors have read and agreed to the published version of the manuscript.

Funding:

The study was supported by the Medical University of Bialystok (SUB/1/DN/21/002/1148). 
medRxiv preprint doi: https://doi.org/10.1101/2021.01.18.21250031; this version posted January 20, 2021. The copyright holder for this preprint (which was not certified by peer review) is the author/funder, who has granted medRxiv a license to display the preprint in perpetuity.

All rights reserved. No reuse allowed without permission.

Acknowledgements:

We would like to thank Mr. Pawel Kowalski from the Chief Inspectorate of Environmental Protection for his help in data interpretation, Mr. Waldemar Kulesza and all the staff at the Department of Epidemiology of the Municipal Sanitary and Epidemiological Station in Bialystok for kindly sharing the epidemiological data.

Conflicts of Interest: The authors declare no conflict of interest.

Availability of data and materials: The data that support the findings of this study are available from the corresponding author on request.

Aintablian, N., Walpita, P., Sawyer, M.H., 1998. Detection of Bordetella pertussis and respiratory synctial virus in air samples from hospital rooms. Infect Control Hosp Epidemiol 19, 918-923. https://doi.org/10.1086/647764

Air quality statistics - European Environment Agency [WWW Document], 2020. URL https://www.eea.europa.eu/data-and-maps/dashboards/air-quality-statistics (accessed 8.19.20).

Boëlle, P.-Y., Souty, C., Launay, T., Guerrisi, C., Turbelin, C., Behillil, S., Enouf, V., Poletto, C., Lina, B., van der Werf, S., Lévy-Bruhl, D., Colizza, V., Hanslik, T., Blanchon, T., 2020. Excess cases of influenza-like illnesses synchronous with coronavirus disease (COVID-19) epidemic, France, March 2020. Euro Surveill 25. https://doi.org/10.2807/1560-7917.ES.2020.25.14.2000326

Brunekreef, B., Holgate, S.T., 2002. Air pollution and health. Lancet 360, 1233-1242. https://doi.org/10.1016/S0140-6736(02)11274-8

Burke, C.W., Bridges, O., Brown, S., Rahija, R., Russell, C.J., 2013. Mode of Parainfluenza Virus Transmission Determines the Dynamics of Primary Infection and Protection from Reinfection. PLoS Pathog 9. https://doi.org/10.1371/journal.ppat.1003786

Burnham, K.P., Anderson, D.R., 1998. Model Selection and Inference: A Practical InformationTheoretic Approach. Springer-Verlag, New York. https://doi.org/10.1007/978-1-4757-2917-7

Chen, P.-S., Tsai, F.T., Lin, C.K., Yang, C.-Y., Chan, C.-C., Young, C.-Y., Lee, C.-H., 2010. Ambient Influenza and Avian Influenza Virus during Dust Storm Days and Background Days. Environ Health Perspect 118, 1211-1216. https://doi.org/10.1289/ehp.0901782

Ciencewicki, J., Jaspers, I., 2007. Air pollution and respiratory viral infection. Inhal Toxicol 19, 11351146. https://doi.org/10.1080/08958370701665434

Comunian, S., Dongo, D., Milani, C., Palestini, P., 2020. Air Pollution and COVID-19: The Role of Particulate Matter in the Spread and Increase of COVID-19's Morbidity and Mortality. Int J Environ Res Public Health 17. https://doi.org/10.3390/ijerph17124487

Conticini, E., Frediani, B., Caro, D., 2020. Can atmospheric pollution be considered a co-factor in extremely high level of SARS-CoV-2 lethality in Northern Italy? Environmental Pollution 261, 114465. https://doi.org/10.1016/j.envpol.2020.114465

Couch, R.B., Cate, T.R., Fleet, W.F., Gerone, P.J., Knight, V., 1966. Aerosol-induced adenoviral illness resembling the naturally occurring illness in military recruits. Am Rev Respir Dis 93, 529-535. https://doi.org/10.1164/arrd.1966.93.4.529

Cowling, B.J., Ip, D.K.M., Fang, V.J., Suntarattiwong, P., Olsen, S.J., Levy, J., Uyeki, T.M., Leung, G.M., Malik Peiris, J.S., Chotpitayasunondh, T., Nishiura, H., Mark Simmerman, J., 2013. Aerosol transmission is an important mode of influenza A virus spread. Nature Communications 4, 1935. https://doi.org/10.1038/ncomms2922 
medRxiv preprint doi: https://doi.org/10.1101/2021.01.18.21250031; this version posted January 20, 2021. The copyright holder for this preprint (which was not certified by peer review) is the author/funder, who has granted medRxiv a license to display the preprint in perpetuity.

All rights reserved. No reuse allowed without permission.

da Silva, P.G., Nascimento, M.S.J., Soares, R.R.G., Sousa, S.I.V., Mesquita, J.R., 2020. Airborne spread of infectious SARS-CoV-2: Moving forward using lessons from SARS-CoV and MERS-CoV. Sci Total Environ 142802. https://doi.org/10.1016/j.scitotenv.2020.142802

Degórska, A., Juda-Rezler, K., Toczko, B., Poland, State Inspection for Environmental Protection, Chief Inspectorate of Environmental Protection (Eds.), 2016. [Fine particles in the atmosphere: a compendium of knowledge about particulate matter air pollution in Poland]. Chief Inspectorate of Environmental Protection, Warsaw.

Dick, E.C., Jennings, L.C., Mink, K.A., Wartgow, C.D., Inhorn, S.L., 1987. Aerosol transmission of rhinovirus colds. J Infect Dis 156, 442-448. https://doi.org/10.1093/infdis/156.3.442

Domingo, J.L., Rovira, J., 2020. Effects of air pollutants on the transmission and severity of respiratory viral infections. Environ. Res. 187, 109650. https://doi.org/10.1016/j.envres.2020.109650

Echavarria, M., Kolavic, S.A., Cersovsky, S., Mitchell, F., Sanchez, J.L., Polyak, C., Innis, B.L., Binn, L.N., 2000. Detection of adenoviruses (AdV) in culture-negative environmental samples by PCR during an AdV-associated respiratory disease outbreak. J Clin Microbiol 38, 2982-2984. https://doi.org/10.1128/JCM.38.8.2982-2984.2000

Feng, C., Li, J., Sun, W., Zhang, Y., Wang, Q., 2016. Impact of ambient fine particulate matter (PM2.5) exposure on the risk of influenza-like-illness: a time-series analysis in Beijing, China. Environmental Health 15, 17. https://doi.org/10.1186/s12940-016-0115-2

Feng, L., Feng, S., Chen, T., Yang, Juan, Lau, Y.C., Peng, Z., Li, L., Wang, X., Wong, J.Y.T., Qin, Y., Bond, H.S., Zhang, J., Fang, V.J., Zheng, J., Yang, Jing, Wu, P., Jiang, H., He, Y., Cowling, B.J., Yu, H., Shu, Y., Lau, E.H.Y., 2020. Burden of influenza-associated outpatient influenza-like illness consultations in China, 2006-2015: A population-based study. Influenza Other Respir Viruses 14, 162-172. https://doi.org/10.1111/irv.12711

Fukuda, K., WHO (Eds.), 2009. Pandemic influenza preparedness and response: a WHO guidance document. World Health Organization, Geneva.

Gasparrini, A., Armstrong, B., Kenward, M.G., 2010. Distributed lag non-linear models. Stat Med 29, 2224-2234. https://doi.org/10.1002/sim.3940

Griffin, D.W., Garrison, V.H., Herman, J.R., Shinn, E.A., 2001. African desert dust in the Caribbean atmosphere: Microbiology and public health. Aerobiologia 17, 203-213. https://doi.org/10.1023/A:1011868218901

Hammond, G.W., Raddatz, R.L., Gelskey, D.E., 1989. Impact of atmospheric dispersion and transport of viral aerosols on the epidemiology of influenza. Rev. Infect. Dis. 11, 494-497. https://doi.org/10.1093/clinids/11.3.494

Huang, L., Zhou, L., Chen, J., Chen, K., Liu, Y., Chen, X., Tang, F., 2016. Acute effects of air pollution on influenza-like illness in Nanjing, China: A population-based study. Chemosphere 147, 180187. https://doi.org/10.1016/j.chemosphere.2015.12.082

lanevski, A., Zusinaite, E., Shtaida, N., Kallio-Kokko, H., Valkonen, M., Kantele, A., Telling, K., Lutsar, I., Letjuka, P., Metelitsa, N., Oksenych, V., Dumpis, U., Vitkauskiene, A., Stašaitis, K., Öhrmalm, C., Bondeson, K., Bergqvist, A., Cox, R.J., Tenson, T., Merits, A., Kainov, D.E., 2019. Low Temperature and Low UV Indexes Correlated with Peaks of Influenza Virus Activity in Northern Europe during 2010²018. Viruses 11. https://doi.org/10.3390/v11030207

Jaspers, I., Ciencewicki, J.M., Zhang, W., Brighton, L.E., Carson, J.L., Beck, M.A., Madden, M.C., 2005. Diesel exhaust enhances influenza virus infections in respiratory epithelial cells. Toxicol. Sci. 85, 990-1002. https://doi.org/10.1093/toxsci/kfi141

Juda-Rezler, K., Reizer, M., Maciejewska, K., Błaszczak, B., Klejnowski, K., 2020. Characterization of atmospheric PM2.5 sources at a Central European urban background site. Sci. Total Environ. 713, 136729. https://doi.org/10.1016/j.scitotenv.2020.136729

Kim, K.-H., Kabir, E., Kabir, S., 2015. A review on the human health impact of airborne particulate matter. Environment International 74, 136-143. https://doi.org/10.1016/j. envint.2014.10.005

Kong, W.-H., Li, Y., Peng, M.-W., Kong, D.-G., Yang, X.-B., Wang, L., Liu, M.-Q., 2020. SARS-CoV-2 detection in patients with influenza-like illness. Nature Microbiology 5, 675-678. https://doi.org/10.1038/s41564-020-0713-1 
Kulkarni, H., Smith, C., Hirst, R., Baker, N., Easton, A., O'Callaghan, C., 2011. Airborne transmission of respiratory syncytial virus (RSV) infection. European Respiratory Journal 38.

Laden, F., Neas, L.M., Dockery, D.W., Schwartz, J., 2000. Association of fine particulate matter from different sources with daily mortality in six U.S. cities. Environ. Health Perspect. 108, 941947. https://doi.org/10.1289/ehp.00108941

Lee, G.I., Saravia, J., You, D., Shrestha, B., Jaligama, S., Hebert, V.Y., Dugas, T.R., Cormier, S.A., 2014. Exposure to combustion generated environmentally persistent free radicals enhances severity of influenza virus infection. Part Fibre Toxicol 11, 57. https://doi.org/10.1186/s12989-014-0057-1

Li, N., Harkema, J.R., Lewandowski, R.P., Wang, M., Bramble, L.A., Gookin, G.R., Ning, Z., Kleinman, M.T., Sioutas, C., Nel, A.E., 2010. Ambient ultrafine particles provide a strong adjuvant effect in the secondary immune response: implication for traffic-related asthma flares. Am. J. Physiol. Lung Cell Mol. Physiol. 299, L374-383. https://doi.org/10.1152/ajplung.00115.2010

Liang, Y., Fang, L., Pan, H., Zhang, K., Kan, H., Brook, J.R., Sun, Q., 2014. PM2.5 in Beijing - temporal pattern and its association with influenza. Environmental Health 13, 102. https://doi.org/10.1186/1476-069X-13-102

Liu, P., Song, M., Zhao, T., Gunthe, S.S., Ham, S., He, Y., Qin, Y.M., Gong, Z., Amorim, J.C., Bertram, A.K., Martin, S.T., 2018. Resolving the mechanisms of hygroscopic growth and cloud condensation nuclei activity for organic particulate matter. Nature Communications 9, 4076. https://doi.org/10.1038/s41467-018-06622-2

Liu, X.-X., Li, Y., Qin, G., Zhu, Y., Li, X., Zhang, J., Zhao, K., Hu, M., Wang, X.-L., Zheng, X., 2019. Effects of air pollutants on occurrences of influenza-like illness and laboratory-confirmed influenza in Hefei, China. Int J Biometeorol 63, 51-60. https://doi.org/10.1007/s00484-018-1633-0

Lowen, A.C., Mubareka, S., Steel, J., Palese, P., 2007. Influenza virus transmission is dependent on relative humidity and temperature. PLoS Pathog. 3, 1470-1476. https://doi.org/10.1371/journal.ppat.0030151

Lowen, A.C., Steel, J., 2014. Roles of Humidity and Temperature in Shaping Influenza Seasonality. J Virol 88, 7692-7695. https://doi.org/10.1128/JVI.03544-13

Merkel, A., 2020. Climate-Data.org [WWW Document]. URL https://en.climatedata.org/europe/poland/podlaskie-voivodeship/bia\%C5\%82ystok-1031/ (accessed 1.9.20).

Morawska, L., Cao, J., 2020. Airborne transmission of SARS-CoV-2: The world should face the reality. Environ Int 139, 105730. https://doi.org/10.1016/j.envint.2020.105730

Myatt, T.A., Johnston, S.L., Zuo, Z., Wand, M., Kebadze, T., Rudnick, S., Milton, D.K., 2004. Detection of airborne rhinovirus and its relation to outdoor air supply in office environments. Am J Respir Crit Care Med 169, 1187-1190. https://doi.org/10.1164/rccm.200306-7600C

Ouyang, W., Guo, B., Cai, G., Li, Q., Han, S., Liu, B., Liu, X., 2015. The washing effect of precipitation on particulate matter and the pollution dynamics of rainwater in downtown Beijing. Science of The Total Environment 505, 306-314. https://doi.org/10.1016/j.scitotenv.2014.09.062

Pinkerton, K.E., Green, F.H., Saiki, C., Vallyathan, V., Plopper, C.G., Gopal, V., Hung, D., Bahne, E.B., Lin, S.S., Ménache, M.G., Schenker, M.B., 2000. Distribution of particulate matter and tissue remodeling in the human lung. Environ. Health Perspect. 108, 1063-1069. https://doi.org/10.1289/ehp.001081063

Polichetti, G., Cocco, S., Spinali, A., Trimarco, V., Nunziata, A., 2009. Effects of particulate matter (PM(10), PM(2.5) and PM(1)) on the cardiovascular system. Toxicology 261, 1-8. https://doi.org/10.1016/j.tox.2009.04.035

Raaschou-Nielsen, O., Andersen, Z.J., Beelen, R., Samoli, E., Stafoggia, M., Weinmayr, G., Hoffmann, B., Fischer, P., Nieuwenhuijsen, M.J., Brunekreef, B., Xun, W.W., Katsouyanni, K., Dimakopoulou, K., Sommar, J., Forsberg, B., Modig, L., Oudin, A., Oftedal, B., Schwarze, P.E., Nafstad, P., De Faire, U., Pedersen, N.L., Ostenson, C.-G., Fratiglioni, L., Penell, J., Korek, M., Pershagen, G., Eriksen, K.T., Sørensen, M., Tjønneland, A., Ellermann, T., Eeftens, M., Peeters, P.H., Meliefste, K., Wang, M., Bueno-de-Mesquita, B., Key, T.J., de Hoogh, K., Concin, H., Nagel, G., Vilier, A., Grioni, S., Krogh, V., Tsai, M.-Y., Ricceri, F., Sacerdote, C., Galassi, C., Migliore, E., Ranzi, A., Cesaroni, G., Badaloni, C., Forastiere, F., Tamayo, I., Amiano, P., Dorronsoro, M., Trichopoulou, A., Bamia, C., Vineis, P., Hoek, G., 2013. Air pollution and lung 
medRxiv preprint doi: https://doi.org/10.1101/2021.01.18.21250031; this version posted January 20, 2021. The copyright holder for this preprint (which was not certified by peer review) is the author/funder, who has granted medRxiv a license to display the preprint in perpetuity.

All rights reserved. No reuse allowed without permission.

cancer incidence in 17 European cohorts: prospective analyses from the European Study of Cohorts for Air Pollution Effects (ESCAPE). Lancet Oncol. 14, 813-822.

https://doi.org/10.1016/S1470-2045(13)70279-1

Sancini, G., Farina, F., Battaglia, C., Cifola, I., Mangano, E., Mantecca, P., Camatini, M., Palestini, P., 2014. Health risk assessment for air pollutants: alterations in lung and cardiac gene expression in mice exposed to Milano winter fine particulate matter (PM2.5). PLoS One 9, e109685. https://doi.org/10.1371/journal.pone.0109685

Saravia, J., You, D., Thevenot, P., Lee, G.I., Shrestha, B., Lomnicki, S., Cormier, S.A., 2014. Early-life exposure to combustion-derived particulate matter causes pulmonary immunosuppression. Mucosal Immunol 7, 694-704. https://doi.org/10.1038/mi.2013.88

Schaffer, F.L., Soergel, M.E., Straube, D.C., 1976. Survival of airborne influenza virus: effects of propagating host, relative humidity, and composition of spray fluids. Arch. Virol. 51, 263273. https://doi.org/10.1007/BF01317930

Shoji, M., Katayama, K., Sano, K., 2011. Absolute humidity as a deterministic factor affecting seasonal influenza epidemics in Japan. Tohoku J. Exp. Med. 224, 251-256. https://doi.org/10.1620/tjem.224.251

Silva, D.R., Viana, V.P., Müller, A.M., Livi, F.P., Dalcin, P. de T.R., 2014. Respiratory viral infections and effects of meteorological parameters and air pollution in adults with respiratory symptoms admitted to the emergency room. Influenza and Other Respiratory Viruses 8, 42-52. https://doi.org/10.1111/irv.12158

Slama, A., Śliwczyński, A., Woźnica, J., Zdrolik, M., Wiśnicki, B., Kubajek, J., Turżańska-Wieczorek, O., Gozdowski, D., Wierzba, W., Franek, E., 2019. Impact of air pollution on hospital admissions with a focus on respiratory diseases: a time-series multi-city analysis. Environ Sci Pollut Res Int 26, 16998-17009. https://doi.org/10.1007/s11356-019-04781-3

Sooryanarain, H., Elankumaran, S., 2015. Environmental role in influenza virus outbreaks. Annu Rev Anim Biosci 3, 347-373. https://doi.org/10.1146/annurev-animal-022114-111017

Statistics Poland - Local Data Bank [WWW Document], 2020. URL https://bdl.stat.gov.pl (accessed 8.4.20).

Stellrecht, K.A., 2017. Chapter 11 - Molecular Testing for Respiratory Viruses, in: Coleman, W.B., Tsongalis, G.J. (Eds.), Diagnostic Molecular Pathology. Academic Press, pp. 123-137. https://doi.org/10.1016/B978-0-12-800886-7.00011-X

Su, W., Wu, X., Geng, X., Zhao, X., Liu, Q., Liu, T., 2019. The short-term effects of air pollutants on influenza-like illness in Jinan, China. BMC Public Health 19, 1319. https://doi.org/10.1186/s12889-019-7607-2

Sun, Q., Hong, X., Wold, L.E., 2010. Cardiovascular effects of ambient particulate air pollution exposure. Circulation 121, 2755-2765. https://doi.org/10.1161/CIRCULATIONAHA.109.893461

Sundell, N., Andersson, L.-M., Brittain-Long, R., Lindh, M., Westin, J., 2016. A four year seasonal survey of the relationship between outdoor climate and epidemiology of viral respiratory tract infections in a temperate climate. J Clin Virol 84, 59-63. https://doi.org/10.1016/j.jcv.2016.10.005

Tai, A.P.K., Mickley, L.J., Jacob, D.J., 2010. Correlations between fine particulate matter (PM2.5) and meteorological variables in the United States: Implications for the sensitivity of PM2.5 to climate change. Atmospheric Environment 44, 3976-3984. https://doi.org/10.1016/j.atmosenv.2010.06.060

Tamerius, J.D., Shaman, J., Alonso, Wladimir J., Alonso, Wladmir J., Bloom-Feshbach, K., Uejio, C.K., Comrie, A., Viboud, C., 2013. Environmental predictors of seasonal influenza epidemics across temperate and tropical climates. PLoS Pathog. 9, e1003194. https://doi.org/10.1371/journal.ppat.1003194

Tang, J.W., Li, Y., Eames, I., Chan, P.K.S., Ridgway, G.L., 2006. Factors involved in the aerosol transmission of infection and control of ventilation in healthcare premises. J Hosp Infect 64, 100-114. https://doi.org/10.1016/j.jhin.2006.05.022

Tellier, R., 2009. Aerosol transmission of influenza A virus: a review of new studies. J R Soc Interface 6, S783-S790. https://doi.org/10.1098/rsif.2009.0302.focus 
medRxiv preprint doi: https://doi.org/10.1101/2021.01.18.21250031; this version posted January 20, 2021. The copyright holder for this preprint

(which was not certified by peer review) is the author/funder, who has granted medRxiv a license to display the preprint in perpetuity.

All rights reserved. No reuse allowed without permission.

Tellier, R., Li, Y., Cowling, B.J., Tang, J.W., 2019. Recognition of aerosol transmission of infectious agents: a commentary. BMC Infectious Diseases 19, 101. https://doi.org/10.1186/s12879019-3707-y

Tsai, Y., Zhou, F., Kim, I.K., 2014. The burden of influenza-like illness in the US workforce. Occup Med (Lond) 64, 341-347. https://doi.org/10.1093/occmed/kqu022

Vandini, S., Corvaglia, L., Alessandroni, R., Aquilano, G., Marsico, C., Spinelli, M., Lanari, M., Faldella, G., 2013. Respiratory syncytial virus infection in infants and correlation with meteorological factors and air pollutants. Ital J Pediatr 39, 1. https://doi.org/10.1186/1824-7288-39-1

WHO, 2006. Air Quality Guidelines: Global Update 2005?]: Particulate Matter, Ozone, Nitrogen Dioxide, and Sulfur Dioxide. World Health Organization.

Xu, Z., Hu, W., Williams, G., Clements, A.C.A., Kan, H., Tong, S., 2013. Air pollution, temperature and pediatric influenza in Brisbane, Australia. Environ Int 59, 384-388. https://doi.org/10.1016/j.envint.2013.06.022

Yang, J., Chen, Y., Yu, Z., Ding, H., Ma, Z., 2019. The influence of PM2.5 on lung injury and cytokines in mice. Exp Ther Med 18, 2503-2511. https://doi.org/10.3892/etm.2019.7839

Ypma, R.J.F., Jonges, M., Bataille, A., Stegeman, A., Koch, G., van Boven, M., Koopmans, M., van Ballegooijen, W.M., Wallinga, J., 2013. Genetic Data Provide Evidence for Wind-Mediated Transmission of Highly Pathogenic Avian Influenza. J Infect Dis 207, 730-735. https://doi.org/10.1093/infdis/jis757

Yu, I.T.S., Li, Y., Wong, T.W., Tam, W., Chan, A.T., Lee, J.H.W., Leung, D.Y.C., Ho, T., 2004. Evidence of airborne transmission of the severe acute respiratory syndrome virus. N Engl J Med 350, 1731-1739. https://doi.org/10.1056/NEJMoa032867

Yu, X., Wei, D., Chen, Y., Zhang, D., Zhang, X., 2020. Retrospective detection of SARS-CoV-2 in hospitalized patients with influenza-like illness. Emerg Microbes Infect 9, 1470-1473. https://doi.org/10.1080/22221751.2020.1785952 


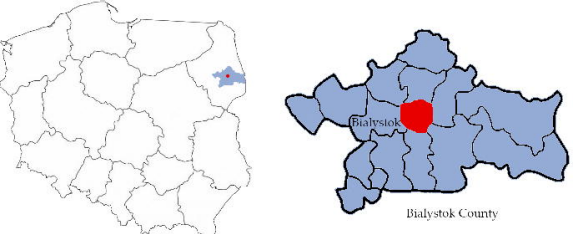




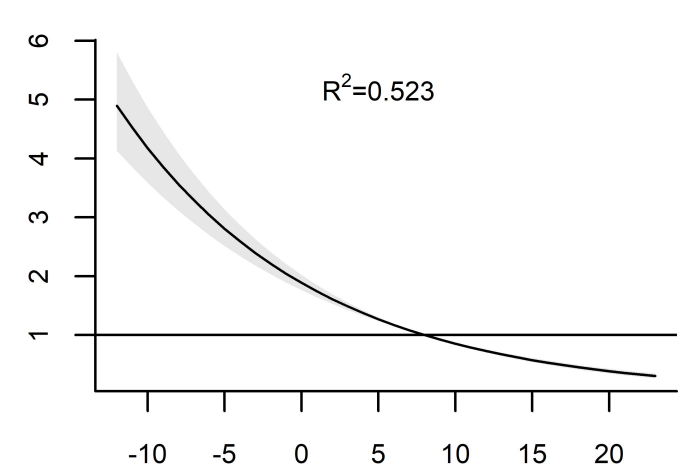

Temperature $\left[{ }^{\circ} \mathrm{C}\right]$

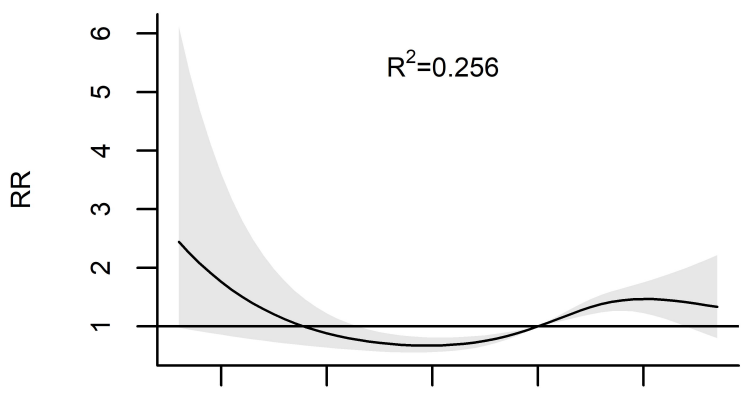

$\begin{array}{lllll}50 & 60 & 70 & 80 & 90\end{array}$

Relative humidity [\%]

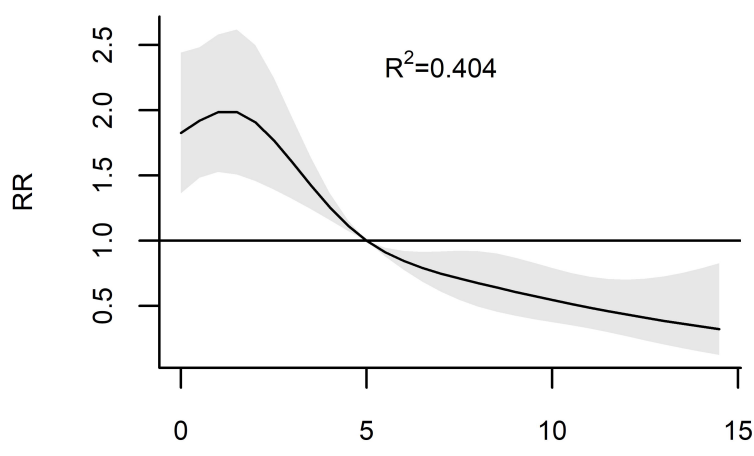

Sunshine duration [hours]
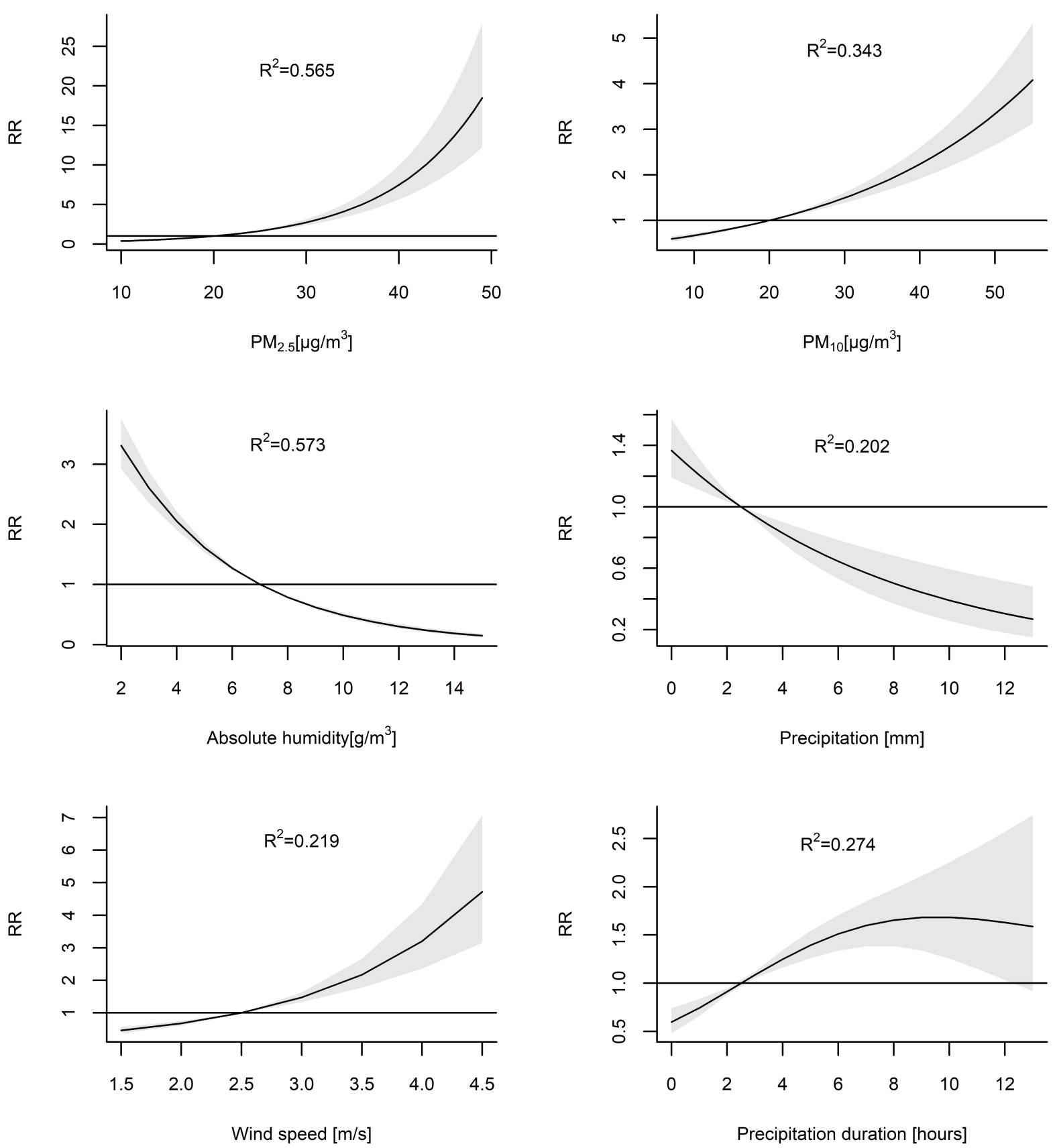


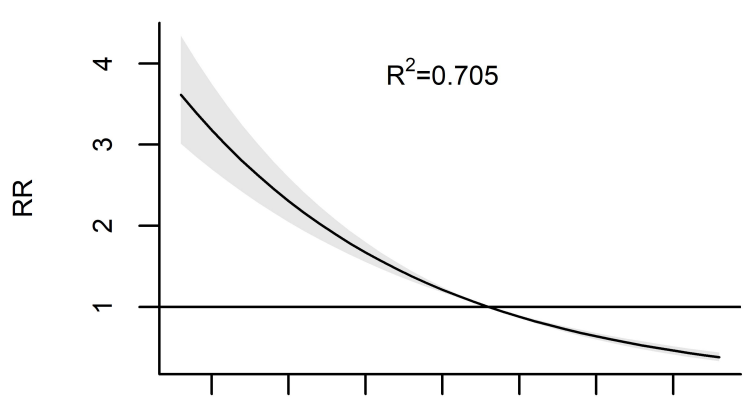

$\begin{array}{lllllll}-10 & -5 & 0 & 5 & 10 & 15 & 20\end{array}$

Temperature $\left[{ }^{\circ} \mathrm{C}\right]$

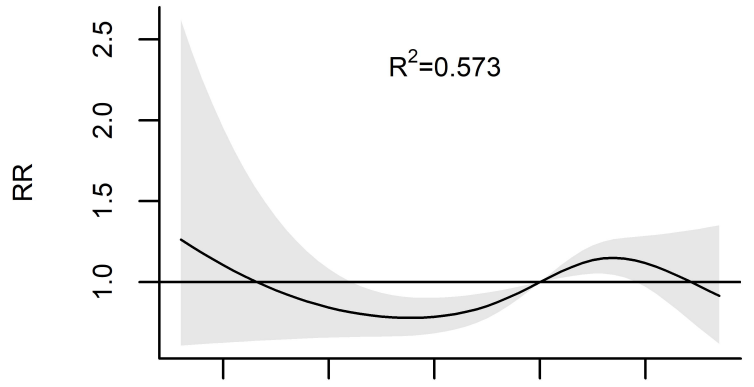

$\begin{array}{lllll}50 & 60 & 70 & 80 & 90\end{array}$

Relative humidity [\%]

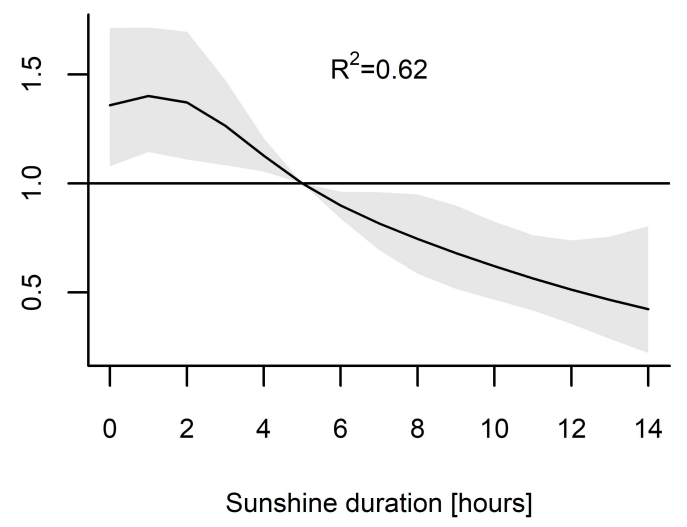

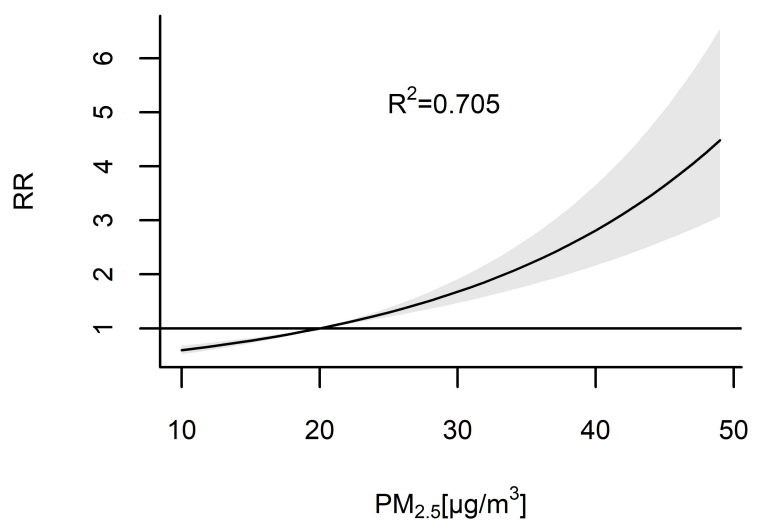
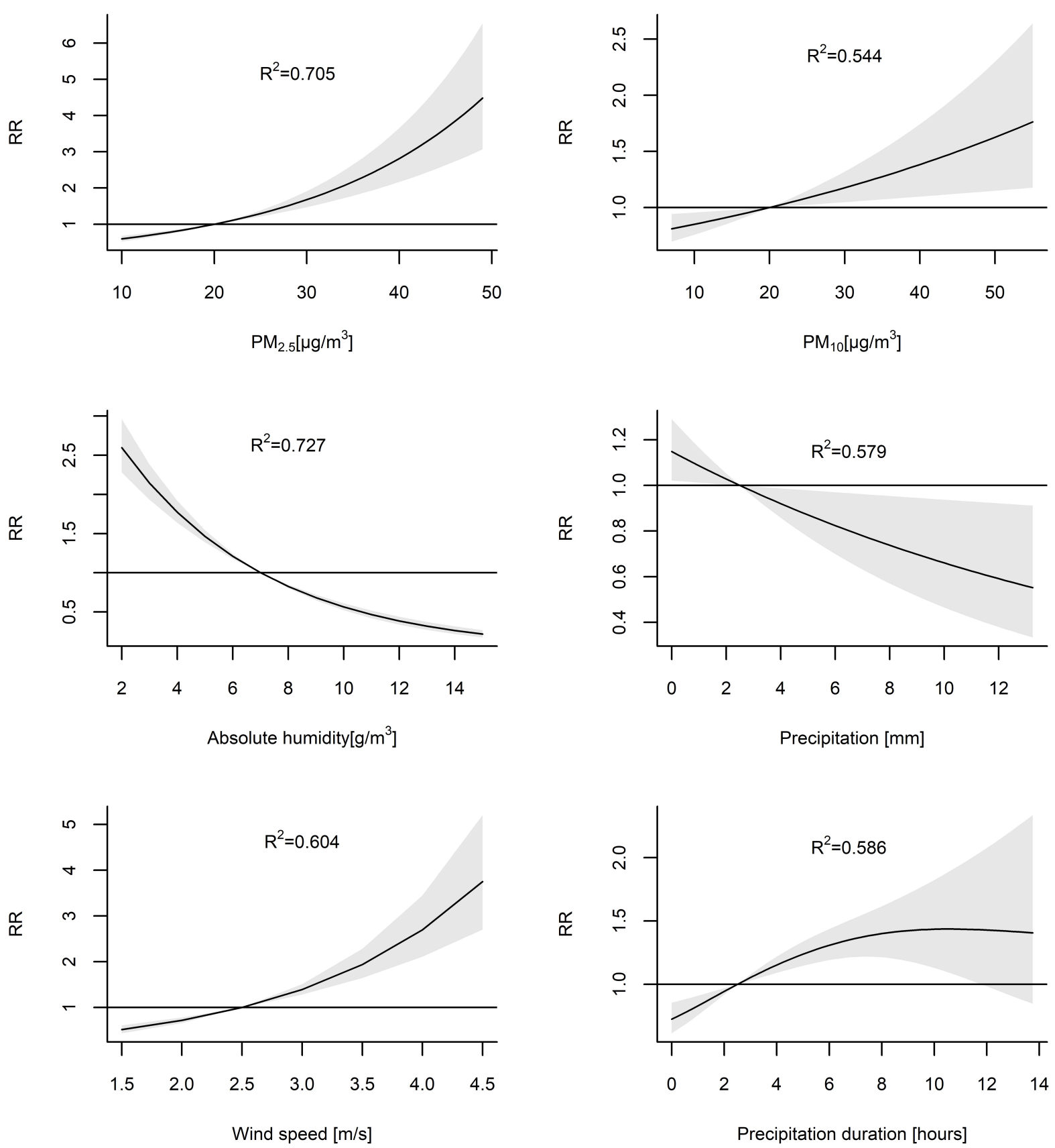


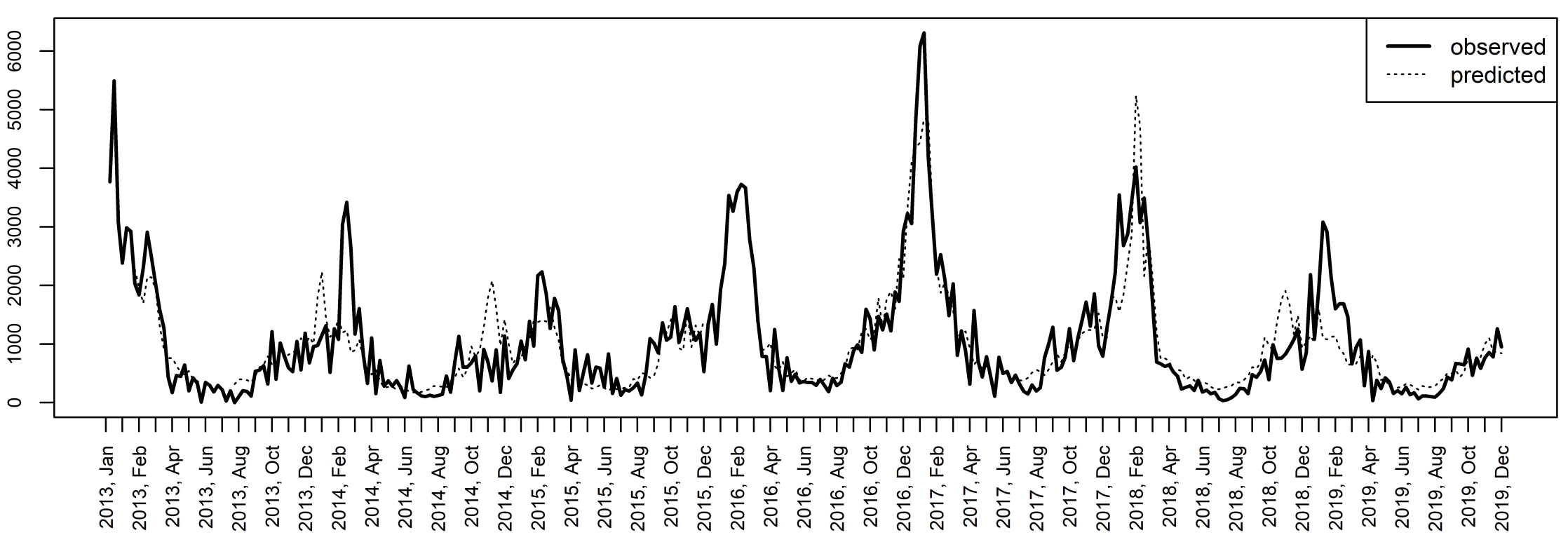




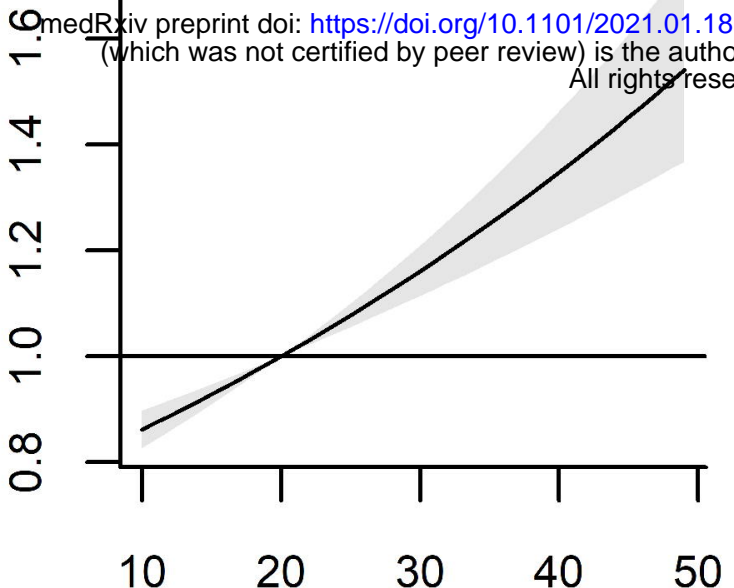

$\mathrm{PM}_{2.5}\left[\mu \mathrm{g} / \mathrm{m}^{3}\right]$

Lag $=3$

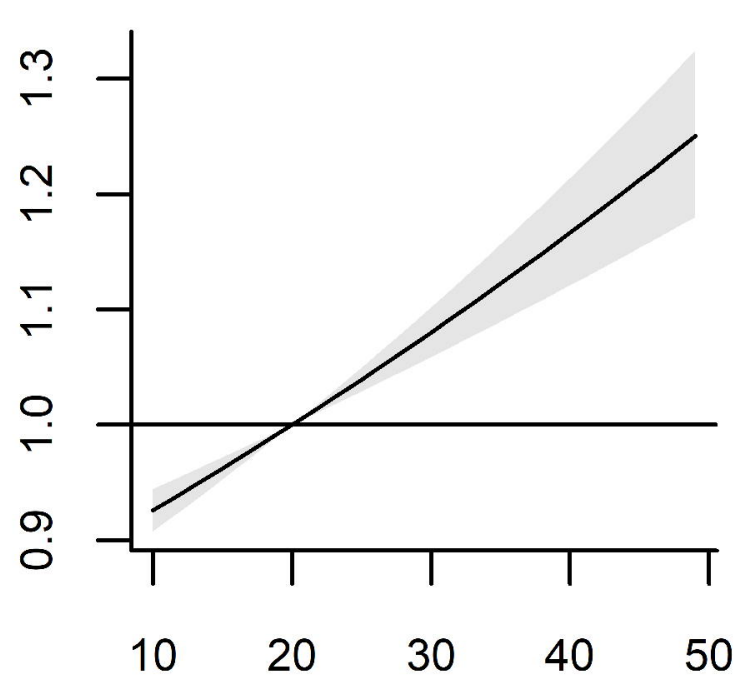

A

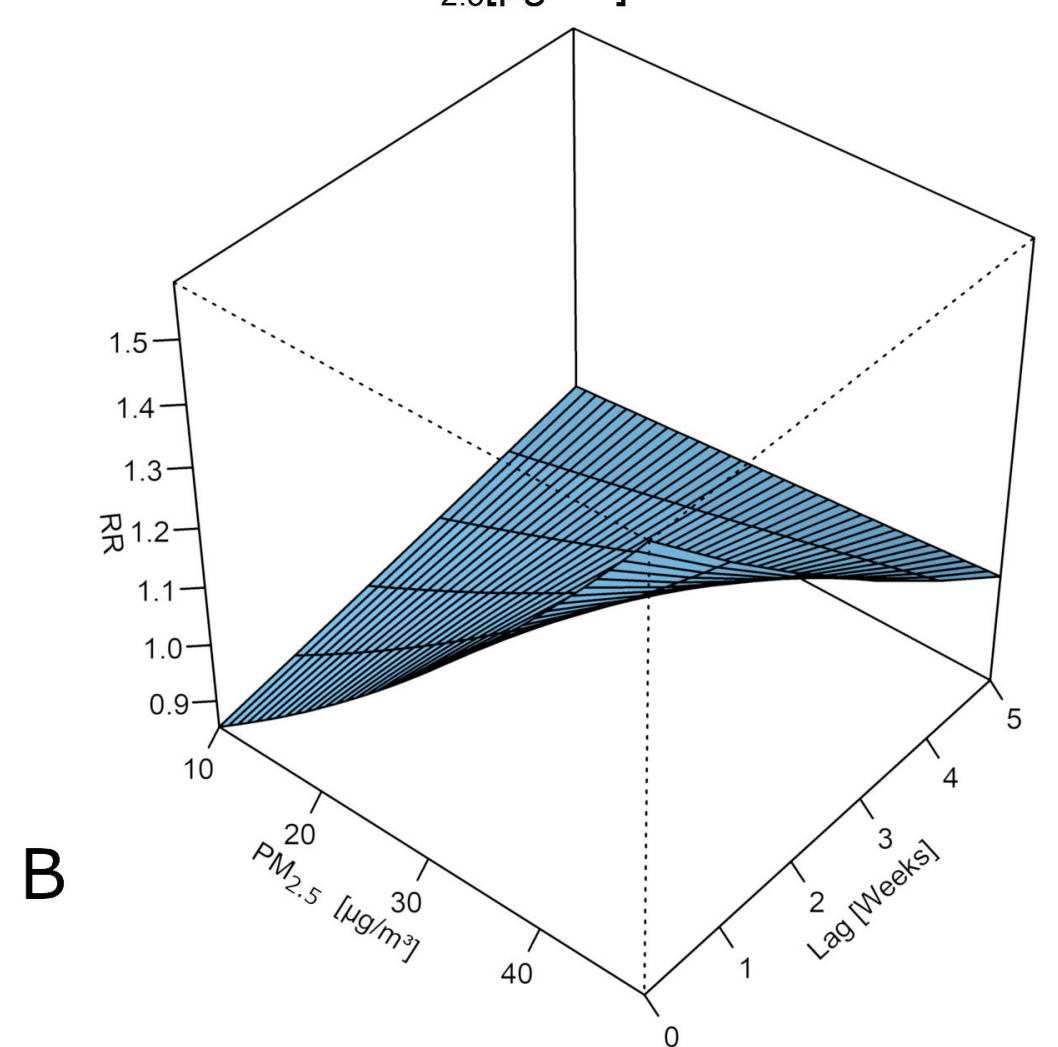

10

7 wi; this version:posted January 20,2021 . The copyright holder for this preprin
who has granted methxiv a license to display the preprint in perpotuty.y. $\stackrel{\propto}{\alpha}$

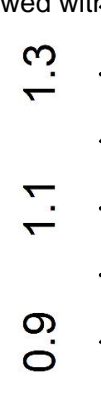

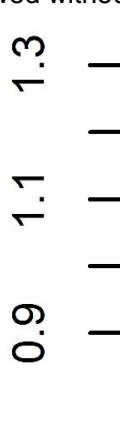
t permission.

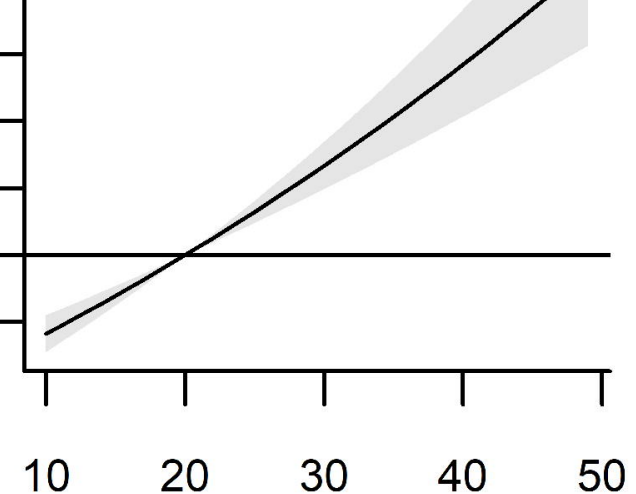

$\mathrm{PM}_{2.5}\left[\mu \mathrm{g} / \mathrm{m}^{3}\right]$

$\operatorname{Lag}=4$

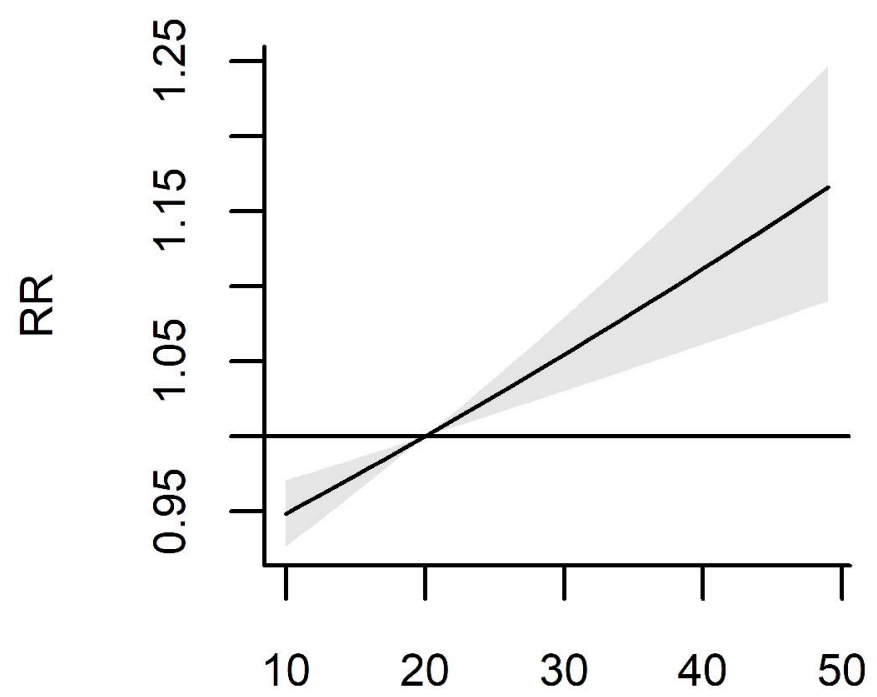

$\mathrm{PM}_{2.5}\left[\mu \mathrm{g} / \mathrm{m}^{3}\right]$

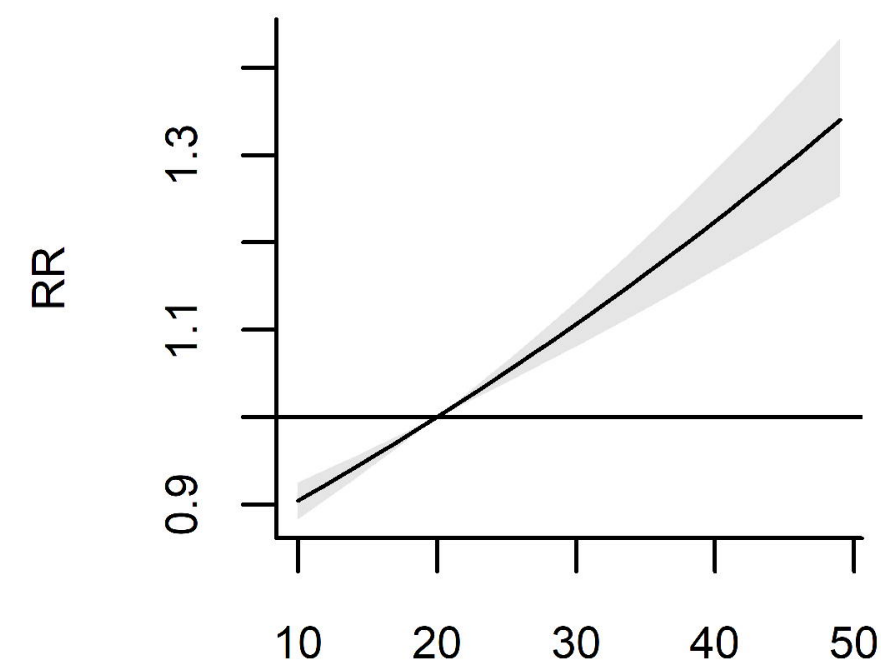

$\mathrm{PM}_{2.5}\left[\mu \mathrm{g} / \mathrm{m}^{3}\right]$

$\operatorname{Lag}=5$

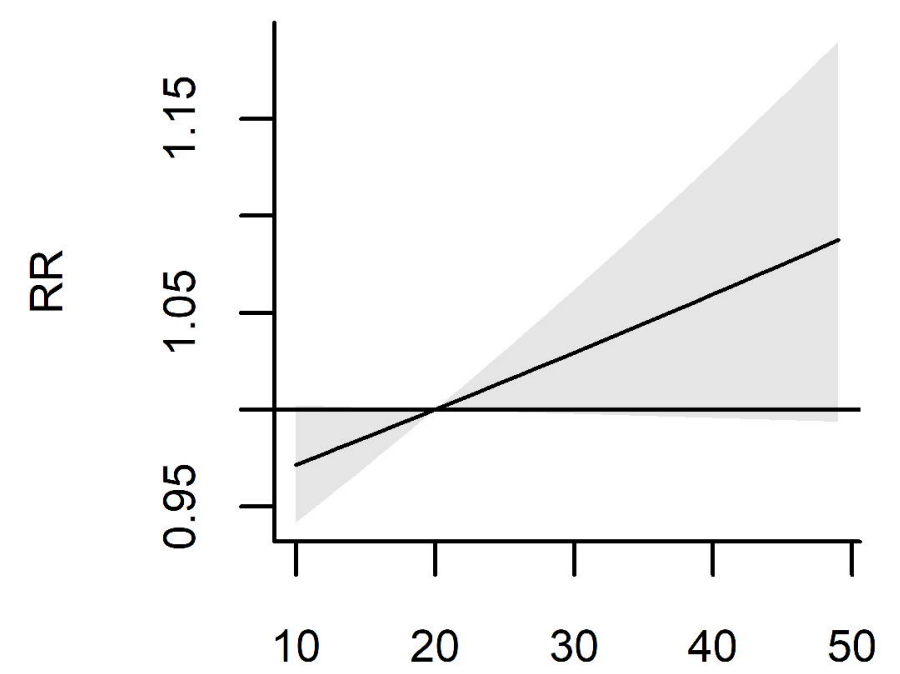

$\mathrm{PM}_{2.5}\left[\mu \mathrm{g} / \mathrm{m}^{3}\right]$

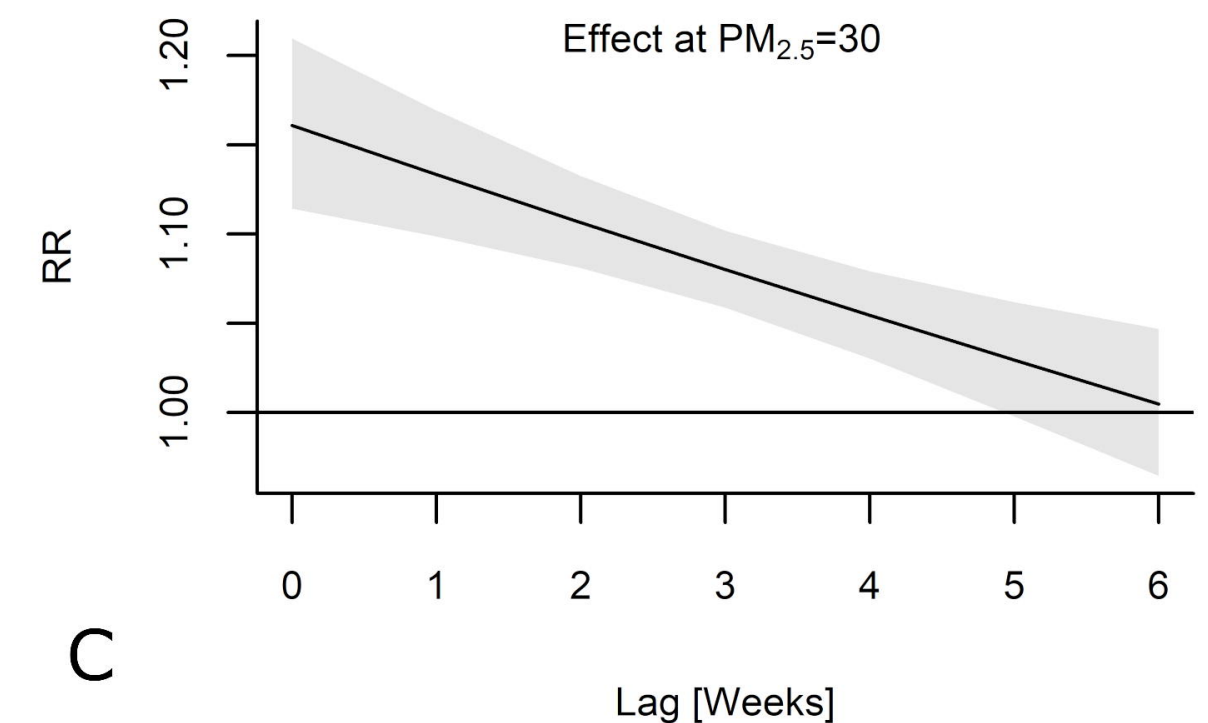

